IZA DP No. 6421

Gender, Economic Development and Islam:

A Perspective from France

Claire L. Adida

David D. Laitin

Marie-Anne Valfort

March 2012 


\title{
Gender, Economic Development and Islam: A Perspective from France
}

\author{
Claire L. Adida \\ University of California, San Diego \\ David D. Laitin \\ Stanford University \\ and IZA \\ Marie-Anne Valfort \\ PSE - Paris 1 Panthéon Sorbonne University
}

Discussion Paper No. 6421

March 2012

\author{
IZA \\ P.O. Box 7240 \\ 53072 Bonn \\ Germany \\ Phone: +49-228-3894-0 \\ Fax: +49-228-3894-180 \\ E-mail: iza@iza.org
}

Any opinions expressed here are those of the author(s) and not those of IZA. Research published in this series may include views on policy, but the institute itself takes no institutional policy positions.

The Institute for the Study of Labor (IZA) in Bonn is a local and virtual international research center and a place of communication between science, politics and business. IZA is an independent nonprofit organization supported by Deutsche Post Foundation. The center is associated with the University of Bonn and offers a stimulating research environment through its international network, workshops and conferences, data service, project support, research visits and doctoral program. IZA engages in (i) original and internationally competitive research in all fields of labor economics, (ii) development of policy concepts, and (iii) dissemination of research results and concepts to the interested public.

IZA Discussion Papers often represent preliminary work and are circulated to encourage discussion. Citation of such a paper should account for its provisional character. A revised version may be available directly from the author. 


\section{ABSTRACT}

\section{Gender, Economic Development and Islam: A Perspective from France ${ }^{*}$}

Muslims do less well on the French labor market than their non Muslim counterparts. One explanation for this relative failure can be characterized by the following syllogism: (1) the empowerment of women is a sine qua non for economic progress; (2) in-group norms among Muslims do not empower women; and hence (3) Muslim communities will underperform economically relative to non-Muslim communities. This paper, relying on a unique identification strategy that isolates religion from national origin and ethnicity, and on experimental as well as survey evidence collected in France, puts this syllogism to a test. Our data show that Muslim and Christian gender norms are as postulated. However, the correlations between Muslim vs. Christian immigrants and the channels purported to link ingroup gender norms to economic progress are weak and inconsistent. Speculations are offered on the intervening variables that mitigate the effect of Muslim gender norms on economic performance.

JEL Classification: C C90, D03, J15, J16, J71, Z12

Keywords: development, Islam, gender, discrimination, France, experimental economics

Corresponding author:

Claire L. Adida

University of California, San Diego

Department of Political Science

Social Sciences Building 389

9500 Gilman Drive, \#0521

La Jolla, CA 92093-0521

USA

E-mail: cadida@ucsd.edu

\footnotetext{
* This research was funded by the National Science Foundation, "Muslim Integration into EU Societies: Comparative Perspectives", Grant SES-0819635, David Laitin, P.I. The authors would like to thank Marisa Abrajano, Ben Adida, Rafaela Dancygier, Jesse Driscoll, Tanya Luhrmann, Neil Malhotra, Craig McIntosh, Megumi Naoi, Christina Schneider, Jasjeet Sekhon, Piero Stanig, Jonathan Wand and participants at the 2011 Princeton University Luce Conference, Annual meeting of the Midwest Political Science Association, Spring meeting of the Working Group on African Political Economy, and Annual Meeting of the American Political Science Association in Seattle, WA.
} 
"[P]atterns of progress and

persistence in gender equality

matter, both for development

outcomes and policy making. They

matter because gender equality is a

core development objective in its

own right. But greater gender

equality is also smart economics,

enhancing productivity and

improving other development

outcomes..."i

\section{Introduction}

The fate of Muslim migrants and their descendants in modern democratic societies is of increasing concern for public policy and consequently in political science (Bleich (2009); Howard (2009); Lawrence and Vaisse (2006)). On a social and political level, relations between Muslim communities and their host societies are reminiscent of a clash of civilizations perspective on inter-state relations (Huntington (1993)). ${ }^{1}$ Values that define today's liberal democracies - such as freedom of the press and gender equality - are challenged by Muslim cultural practices, such as the prohibition to profane what is considered sacred (Klausen (2009)) and the veiling of Muslim women (Bowen (2007)). Initiatives to restrict veiling, for instance, have taken legislative form in a number of European countries such as Denmark, the Netherlands, Italy, Belgium and France. ${ }^{2}$ Furthermore, on an

${ }^{i}$ See the 2012 World Bank Development Report, which is dedicated to gender equality and development (The World Bank (2011)).

${ }^{1}$ Sniderman and Hagendoorn (2007), using a set of survey experiments in the Netherlands, and Bowen (2007), using ethnographic observations in France, highlight systematic intolerance of Muslim immigrants by the rooted populations of Europe that see their cultures under threat.

${ }^{2}$ Recent work suggests that such prohibitions might actually have negative effects on integration. Meyersson (2011), relying on a regression discontinuity design, shows how bans on religious 
economic level, Muslim immigrants are less integrated than their non-Muslim counterparts: Adida, Laitin, and Valfort (2010) show, in the case of France, that relative to a matched set of Christian immigrants (and thus controlling for national origin, race, ethnicity, socio-economic status and other key demographic variables), Muslim immigrant households earn on average 400 euros less than Christian immigrant households each month (equivalent to $14 \%$ of the average monthly income in France in 2009). Lower economic integration on the part of Muslims in France, these authors argue, is partly due to labor-market discrimination: results from a correspondence test show that Muslim applicants are 2.5 times less likely to receive a callback for an interview than are their otherwise-matched Christian counterparts.

Political scientists have offered several accounts for the apparent failure of Muslim integration into Christian-heritage societies such as France. One of the principal accounts focuses on gender norms (Fish (2011); Inglehart (2003)) and supports a conventional wisdom about Muslims, women and economic progress, illustrated in the epigraph and systematized with the following syllogism: (1) the empowerment of women is a sine qua non for full-fledged economic progress; (2) in-group norms among Muslims do not empower women to the degree to which in-group norms among non-Muslims do. Therefore, (3) Muslim communities will underperform economically relative to non-Muslim communities. ${ }^{3}$

Previous work has provided evidence on each of the elements of this syllogism, but its full logic has not yet been explored empirically. On the first premise, there is wide agreement (Behrman in Tilak (2003); Duflo (2011); Schultz in King and Hill (1993)), and the literature highlights two channels through which female empowerment promotes economic progress. The first is a human capital channel: female education is correlated with female earnings (Duflo (2011)), and has been shown to lower fertility rates (Breierova and Duflo (2004)) and improve child mortality (Chou expression - such as veiling - in public institutions in Turkey raise barriers to entry in education and the labor market and thus may do more harm than good for Muslim women. Similarly, Carvalho (2011) argues that veiling among Muslim women is a strategy for integration.

${ }^{3}$ Although the syllogism is of our construction, Nobelist A. K. Sen aroused the policy community and social scientists in similar terms about the implications of oppressive gender norms for development (see Duflo (2011)). 
et al. (2010)). The policy world has embraced this view whole-heartedly, claiming that education has a "catalytic effect on every dimension of development" (former World Bank President James Wolfensohn, as cited in Duflo (2011)). The second is a bargaining-power channel: e.g., providing women greater bargaining-power in household decisions translates into higher female participation in the labor force; it also improves child health (Duflo (2003); Thomas (1990)).

The second premise finds more ambiguous support. Caldwell (2009), Fish (2011), Inglehart (2003) and Sharabi (1988), mostly relying on surveys or sociological accounts, offer evidence linking Islam and the repression of women. But Ross (2008) presents data revealing that the sources of women's absence in the labor force and in political representation lie with oil rather than religion. As for the syllogistic conclusion, the evidence is therefore similarly ambiguous. A World Bank report, for example, shows no consistent relationship between gender norms of Muslims and Muslim countries' economic development (The World Bank (2001): 112). In sum, a syllogism linking Islam, gender and economic failure may be conventional wisdom in some circles, but it is hardly conclusive.

Our paper puts this syllogism to a test by bringing experimental data to bear on the premise that in-group gender norms among Muslims do not empower women to the degree to which in-group gender-norms among non-Muslims do. To do so, it uses a unique identification strategy. Relying on experimental data with a sample of Serer and Joola immigrants to France - two language communities from Senegal that are similar in race and culture but divided along religious lines, and that migrated to France at the same time - this paper isolates the religious effect on gender norms. We call these Muslim and Christian immigrants our Senegalese subjects, and refer to Senegalese Muslims as SM and Senegalese Christians as SX. ${ }^{4}$ We compare the donations of SM and SX players to co-ethnic and non co-ethnic male and female recipients in a dictator game. Therefore, controlling for national origin and ethnicity, this paper identifies the Muslim effect on in-group gender norms and confirms that Muslim gender norms differ significantly from non-Muslim gender norms. In so doing, it improves upon the literature in two ways. First (with the exception of Ross (2008)),

\footnotetext{
${ }^{4}$ See Adida, Laitin, and Valfort (2010) for a comprehensive description of the ways in which these groups compare.
} 
studies on Muslim gender norms so far fail to isolate the Muslim effect from possible confounds, such as race, ethnicity, or nationality. Our study successfully avoids such confounds. Second, existing research relies on survey measures or cross-national indicators of discrimination and thus never looks directly at discriminatory behavior. ${ }^{5}$ By contrast, the data we use to identify gender norms are behavioral: we measure players' donations in a dictator game with monetary stakes.

Our dictator game results indicate significant differences in gender behavior between the two matched religious groups: (1) SM male players are less generous toward the average female recipient (but not toward the average male recipient) than are SX male players, largely due to the fact that SX male players give more to the average female recipient than to the average male recipient; (2) SM male players discriminate against SM women relative to SM men. This is in comparison to SX male players who are more generous toward SX women than SX men. (3) SM female players give less to SM women than to SM men (but give equally to the average male and female recipients), thereby taking an active part in supporting an in-group norm that favors co-ethnic men over women. This last result is consistent with Blaydes and Linzer (2008), who show that many women in Muslim countries - in particular those facing financial insecurity - subscribe to fundamentalist beliefs and practices to improve their opportunities on the marriage market. Our experimental strategy thus enables us to demonstrate that, ceteris paribus, the syllogism holds.

In a second set of tests relying on a mixed-methods approach that draws from survey and experimental data, we analyze the correlation between SM immigrant households (vs. SX immigrant households), and three possible channels through which Muslim gender norms might account for lapsed economic integration: ${ }^{6}$ (1) the human capital channel, whereby SM women are less educated than SX women; (2) the bargaining-power channel, whereby SM women have less of a say in

\footnotetext{
${ }^{5}$ There are a couple of notable exceptions. First, Delavande and Zafar (2011) identify gender discrimination in the educated Pakistani society using an experimental approach. However, their empirical strategy does not identify a religious effect. Second, ethnographic data present direct evidence of discriminatory behavior; this approach, however, typically suffers from selection bias by looking only at the more conservative Muslim families. See, for example, Kakpo (2007): chapter 3.

${ }^{6}$ The first two channels are well-established in the literature. The third is our addition, and is inspired by results in Adida, Laitin, and Valfort (2010).
} 
household decisions than do SX women; and (3) the recruiter channel, whereby French recruiters perceive Muslim gender norms and refuse to hire candidates they believe to be threatening to the work environment. ${ }^{7}$ We provide indirect tests of all three of these channels and find no conclusive evidence that there is a link between in-group gender norms among Muslims and their lower economic performance relative to their Christian counterparts.

In sum, we assume the first premise - widely researched and demonstrated - concerning gender rights and development. We then provide conclusive evidence for the second premise by identifying a relationship that shows a significant difference in gender norms among Muslims compared to a matched set of Christians. However, our correlational data on the links between religious gender norms and three channels conducive to economic performance fail to give strong support to the logic of the syllogism. While the syllogism may hold ceteris paribus, the world is not ceteris paribus: we explore intervening factors, specific to the French context, that might mitigate the negative implications of the syllogism for the economic success of Muslim immigrants in France. We conclude that the relationship between gender norms and economic integration among Muslims is much more complex than today's conventional wisdom would have us believe.

We proceed as follows. In section 2, we review the secondary literature in support of the two premises underlying the syllogism that links Muslim economic underperformance to Muslim gender discrimination: the positive impact of female empowerment on economic development and the existence of gender discrimination among Muslims. In sections 3 and 4, we report the results of our empirical test of the second premise of the syllogism, and of the correlation between religious gender norms and three channels conducive to economic development. Section 5 interprets these results. Section 6 addresses concerns of measurement and external validity. Finally, section 7 summarizes and concludes with implications for the economic integration of Muslim immigrants into Western societies.

\footnotetext{
${ }^{7}$ In fact, our experimental data indicate that SX gender norms are in line with rooted French gender norms (results available upon request), in that in the context of allocations in a dictator game, both favor women over men.
} 


\section{Islam, women and development}

Why might gender norms explain the deficit in Muslim immigrant integration in France? Today's conventional wisdom relies on a syllogism linking female empowerment to economic progress on one hand, and Islam to female discrimination on the other. In this section, we survey what the academic literature says about each of these premises.

\subsection{Women empowerment and economic development}

In a literature review on the empowerment of women and economic development, Duflo (2011) distinguishes between the two channels through which the empowerment of women might promote economic development: education and bargaining-power. We consider the evidence for each of these below.

\subsubsection{The education channel}

In their review of the theoretical and empirical literature on gender equity, Abu-Ghaida and Klasen (2004) emphasize the positive role that female education plays in determining growth. These findings are unambiguous, showing not only that there are direct benefits to educating girls, ${ }^{8}$ but also that a number of positive externalities to female education exist. These range from the quantity and quality of children's education, improved child health and nutrition, reduced fertility, and a larger share of the working age population in the total population, thus increasing per capita economic growth (Abu-Ghaida and Klasen (2004): 1079). For example, their review shows that an extra year of female schooling reduces fertility by 0.3 to 0.5 children per woman and child mortality by 18.1 per 1,000 in 1990 (Abu-Ghaida and Klasen (2004): 1083-4).

\footnotetext{
${ }^{8} \mathrm{Abu}-\mathrm{Ghaida}$ and Klasen write that "the negative impact of gender inequality in education on growth has been substantiated in studies that use a growth regression framework addressing problems of multicollinearity, simultaneity, and specific issues (Forbes (2000); Klasen (2002); Klasen and Lamanna (2003); Yamarak and Ghosh (2003)) and a Solow framework (Hill and King (1995); Knowles, Lorgelly, and Owen (2002))" Abu-Ghaida and Klasen (2004): 1082.
} 
Duflo (2011)'s review further corroborates the positive effects of female education on outcomes that matter for development, although she qualifies the evidence as less strong than is commonly believed. Breierova and Duflo (2004), for example, demonstrate that female education lowers fertility rates in Indonesia. In Taiwan, Chou et al. (2010) show that the introduction of compulsory junior secondary schooling in 1968 reduced child mortality.

\subsubsection{The bargaining-power channel}

Empirical and theoretical evidence linking female bargaining-power and development abound. Doepke and Tertilt (2010) show, in their literature review, that female empowerment (at least within the household) yields outcomes amenable to development. They summarize results showing that female empowerment increases expenditures on children's clothing (Lundberg, Pollack, and Wales (1997); Phipps and Burton (1998)), food (Doss (2006); Duflo and Udry (2004); Gitter and Barham (2008); Hoddinott and Haddad (1995); Phipps and Burton (1998)), child care (Phipps and Burton (1998)), education (Doss (2006); Pitt and Khandker (1998)) and child health (Atkin (2009); Duflo (2000); Duflo (2003); Thomas (1990)); it decreases expenditures on alcohol and cigarettes (Case and Deaton (1998); Doss (2006); Hoddinott and Haddad (1995); Kennedy and Peters (1992)). Duflo (2011) confirms that the literature demonstrates a positive link between female bargainingpower in the household and development outcomes such as child health.

The link between female education and development on one hand, and between female bargainingpower and development on the other, is - in a wide range of reports - not only statistically but also substantively significant. ${ }^{9}$ But what do we know of the link between Islam and the treatment of women?

\footnotetext{
${ }^{9}$ Note, however, that Doepke and Tertilt (2010) point out that their reported results on women's bargaining power are only partial equilibria, and could be undermined in a general equilibrium analysis. For example, if women's household bargaining power increased, their consumption preferences could regress toward that of their husbands.
} 


\subsection{Islam and discriminatory gender norms}

Scholarship on the place of women in Islam and among Muslims delivers ambiguous results. Historical accounts of women's status in the Middle East claim that Islamic traditions explain female repression in both public and private life in the region (Mernissi (1987), Sharabi (1988)). ${ }^{10}$ Crosscountry analyses have shown that Muslim-majority countries tend to repress their women (Alexander and Welzel (2011); Boone (1996); Dollar and Gatti (1999); Hajj and Panizza (2009)). Survey analysis has corroborated this (Fish (2011); Inglehart and Norris in Inglehart (2003)). And a comprehensive scholarship has focused on explaining why and how Islamic fundamentalism represses women (Blaydes and Linzer (2008)).

More recently, carefully controlled analyses that emphasize the role of confounding factors suggest instead that there is no significant relationship between Islam and the repression of women. Ross (2008) contends that oil is an important omitted variable that accounts for female underrepresentation in public life in oil-abundant Muslim countries. ${ }^{11}$ Hajj and Panizza (2009) analyze individual-level data and use a difference-in-difference approach to compare the investment of Muslims and Christians in female education in Lebanon. They find "that other things equal, both Muslim and Christian girls receive more education than their male counterparts, and that there is no significant (either statistical or economic) difference between the education gender gap of Muslims and Christians" (Hajj and Panizza (2009): 344).

But popular opinion, and what is now becoming conventional wisdom, asserts that Muslims treat women differently. Scholars relying on the World Values Survey point to the fact that the only place where the Muslim world is consistently different from the rest is with regard to gender issues (Fish (2011)). And one top-selling book trying to understand Muslim integration in Europe buys wholesale this conventional wisdom, for example in arguing that Muslim males prefer to import women from the home country, who are ignorant of their rights in the host country, in order

\footnotetext{
${ }^{10}$ Mernissi (1987) focuses on the role that male theologians played in distorting religious texts to preserve a patriarchal system.

${ }^{11}$ According to Ross, oil production reduces the number of women in the work force; this suppresses their political influence (Ross (2008)).
} 
to perpetuate antediluvian gender roles (Caldwell (2009): 226).

In this paper, we put this second premise to a test. In doing so, we bring systematic analysis to a contentious question, and build on the latest academic work in two ways. First, we successfully isolate the Muslim effect from potential confounds. To the best of our knowledge, Hajj and Panizza (2009) are the only ones to overcome this problem with their single-country survey analysis of Lebanese Christians (the Maronites) and Muslims (both Shi'as and Sunnis). ${ }^{12}$ But other work conflates religion with ethnicity, race or national origin. ${ }^{13}$ Second, quantitative analyses of the effect of Islam on gender equality focus either on broad indicators of gender equality (as Ross does by looking at female participation in the workforce and as Boone does by looking at indicators of human rights abuses) or on individual attitudes toward women (as Fish, and Inglehart and Norris do by looking at the World Values Survey). What is missing is an approach that explicitly captures individual discriminatory behavior. ${ }^{14}$

\footnotetext{
${ }^{12}$ Still, problems remain: they rely on regression analysis of two populations that share only a small overlap in their distributions across the dimension of socio-economic status, introducing estimation bias in regression analyses. This is because the algorithm used in regression analysis extrapolates from a comparison of those overlapping populations (i.e. rich Muslims with poor Maronites), two population sub-sets that surely differ on many unobservables. Our strategy, to be explained in the following section, avoids this problem, as the overlap in socio-economic status between our comparison groups is large.

${ }^{13}$ Read and Oselin (2008) offer a small-N study of Christian and Muslim Arab-Americans in Houston, Texas. However, their sample relies on respondents who are originally from a diversity of countries, including Syria, Lebanon, Jordan, Egypt, Libya, and Kuwait. The authors do not control for country-of-origin. Similarly, Read (2004) analyzes the employment rates of a nationally representative, medium-N survey of Christian and Muslim Arab-American women; she does not, however, control for country-of-origin.

${ }^{14}$ Delavande and Zafar (2011) offer an experimental investigation into gender discrimination among educated Pakistanis; they do not, however, identify a Muslim effect.
} 


\section{Testing the relationship between Islam and gender norms}

\subsection{Data and research design}

To address the premise that Muslims are less generous toward women than are non-Muslims, we designed a dictator game where we analyze differential donations toward men vs. women, interpreting differential donations in this dictator game as an indicator of discrimination. ${ }^{15} \mathrm{We}$ understand discrimination to be the outcome when individuals, in specified transactions, condition their behavior on criteria of groups of people that are irrelevant to those transactions, with welfare effects on those people who meet such criteria.

Our version of the dictator game is played among a series of experimental games, in which we bring together our Senegalese players and a quasi random sample of residents living in the diverse 19th district of Paris. We chose to conduct our games in this ethnically diverse setting because we did not want any of our players to consider the ethno-religious diversity of our game sessions (and notably the presence of SM and SX players) as exceptional, thus avoiding potential socialdesirability bias in their behavior. The non-Senegalese players were solicited at twenty-one metro stations within that district. Recruiters were sent to these stations by a population-weighted lottery, and for each station/day of recruitment, we randomly drew a number for how many passers-by to ignore between solicitations. ${ }^{16}$ Recruits were told that they could earn up to 148 euros for two and a half hours of play; turn downs were at about 30 percent. $^{17}$

We recruited 29 Senegalese players - 18 self-identified as Muslims (SM) and 11 as Christians (SX) - from three separate networks. Two of the networks came from ethnographers who were

\footnotetext{
${ }^{15}$ The dictator game was introduced by Kahneman et al. (1986). Camerer (2003) provides a useful review.

${ }^{16}$ We deviated from this number if we saw a passer-by who appeared to be a rooted French resident, as we needed to overdraw from this segment of the population for aspects of our protocol not relevant to this paper; we thus call our procedure quasi-random. By rooted French, we refer to French citizens with four grandparents born inside metropolitan France. We identify this set in order to maximally differentiate French citizens with no recent immigrant background from those of recent migration to France.

${ }^{17}$ For purposes of ethical oversight, all experimental protocols were reviewed and approved by the Stanford University IRB.
} 
conducting family histories for our wider research project; they were asked to recruit Senegalese subjects by merely telling them they had heard about experiments with a chance to earn a lot of money. No mention was made about Senegalese specificity or religion. The third network came from a Senegalese night watchman who worked at a student dorm. He was given a quota and paid for each recruit who showed up to participate in the games. Here again, no mention was made about Senegalese specificity or region. ${ }^{18}$ Table 1 presents summary statistics for our two target populations, SM and SX. ${ }^{19}$

In our version of the dictator game, players (whom we call dictators) sat in groups of ten in a single room and were shown the same set of six partners (whom we call recipients) on a large screen revealing only their faces and their first names. The dictators were asked to make a decision to allocate $\mathrm{a}=\{0,1,2,3,4,5\}$ euros to each recipient, out of 5 euros allotted to them for each recipient. Dictators were handed a piece of paper and provided with enough space to record their decisions in a private manner, albeit in a public space. We varied the first names of the recipients such that dictators would see the same face but with alternated religious identities. More precisely, among the six recipients, two were apparent rooted French with typical French names, two were ambiguous with alternatively Muslim and Christian names (such that dictators could reasonably think they were rooted French with Christian names or North Africans with Muslim names), and two were apparent black Africans (these were our Senegalese recipients, alternatively SM or SX). For half of the sessions, subjects viewed one of the ambiguous recipients and one of the Senegalese recipients with a Christian name and the other with a Muslim name; for the other half of the sessions, this was reversed. The purpose of this treatment is to avoid confounds between the ethnic type of the recipient and the face of the recipient.

Figure 1 illustrates the faces and alternating names of our recipients. It shows, for example, that

\footnotetext{
${ }^{18}$ For greater elaboration on the recruitment of the full subject pool, see Adida, Laitin, and Valfort (2012).

${ }^{19}$ Note that Table 1 indicates that the Senegalese Muslims and Christians sampled do not differ significantly on a number of critical variables, such as household income. They do differ on their level of religiosity, with SX significantly more religious than SM. This introduces a bias that we control for in subsequent analysis. Moreover, this bias runs against us finding religiously-based differences in gender norms that work against women.
} 
a random half of our dictators could choose to give money to Khadija and Michel, while the other random half could choose to give money to Joséphine and Aboubacar. Khadija and Joséphine on one hand, and Michel and Aboubacar on the other, are exactly the same recipient: the only parameter that varies is their first name, one that signals a Muslim affiliation (Khadija and Aboubacar) and one that signals a Christian affiliation (Joséphine and Michel). This protocol thus allows us to measure generosity levels of SM and SX dictators toward male and female rooted French recipients $(\{$ Jean-Marc, Georges $\}-\{$ Sylvie, Christine $\})$, toward male and female North African recipients (Mohammed - Farida) and toward male and female co-ethnic recipients ((Aboubacar - Khadija) and (Michel - Joséphine)), all else equal. A difference-in-difference analysis, such as the one that compares the donations to (Khadija - Aboubacar) versus the donations to (Joséphine - Michel), cleanly isolates the effect of gender on generosity levels among matched Christian and Muslim dictators.

\subsection{Empirical results}

Results from our 2009 dictator game described above permits us to analyze (a) the behavior of both male and female dictators to identify the drivers of discrimination; and (b) donations to all female recipients, to rooted French female recipients, and to co-ethnic female recipients. We begin with an analysis of male behavior, since men are typically assumed to be the perpetrators of gender discrimination.

\subsubsection{Finding 1: SX male dictators favor women over men, while SM male dictators do not.}

Table 2.A provides a first glance at SM and SX male behavior toward male vs. female recipients. We find that SM male dictators give on average 0.70 euros to male recipients, but only 0.27 euros to female recipients. This difference of 0.43 euros is significant at the $90 \%$ confidence level. By contrast, SX male dictators offer 1.53 euros to male recipients and 1.67 euros to female recipients, a difference that is not statistically significant. The difference-in-difference, therefore, is statistically significant at the $99 \%$ confidence level. 
With proper controls, the data show that a clear difference between our male SX and SM dictators prevails, but that it is driven by relative SX male generosity rather than SM male miserliness toward women. Table 3 illustrates these patterns via the following model applied only to SM male and SX male dictators:

$$
\begin{aligned}
\text { Donation }= & a+b_{1} \cdot(\mathrm{SM} \rightarrow \text { FemaleRecipient })+b_{2} \cdot(\mathbf{S X} \rightarrow \text { MaleRecipient }) \\
& \left.+b_{3} \cdot(\mathbf{S X} \rightarrow \text { FemaleRecipient })+\mathbf{b}_{\mathbf{4}}^{\prime} \cdot(\mathbf{X})+\mathbf{b}_{\mathbf{5}}^{\prime} \cdot(\text { Session(Mundlak-Chamberlain })\right) \\
& +\mathbf{b}_{\mathbf{6}}^{\prime} \cdot(\text { RecipientEthnoReligiousID })+\mathbf{b}_{\mathbf{7}}^{\prime} \cdot(\text { RecipientFace })+e
\end{aligned}
$$

where Donation refers to the amount given by the dictators to the recipients in the dictator game. The dummy $S M \rightarrow$ FemaleRecipient is equal to 1 if the dictator is SM and the recipient is female, and to 0 otherwise. Similarly, the dummy $S X \rightarrow$ MaleRecipient is equal to 1 if the dictator is SX and the recipient is male, and to 0 otherwise; and the dummy $S X \rightarrow$ FemaleRecipient is equal to 1 if the dictator is SX and the recipient is female, and to 0 otherwise. The omitted interaction is the donation of SM dictators to male recipients. Coefficient $b_{1}$ thus compares the donation of SM dictators to female recipients with that of SM dictators to male recipients. Coefficients $\left(b_{3}-b_{2}\right)$ compare the donation of SX dictators to female recipients with that of SX dictators to male recipients. With $X$, we control for a vector of socioeconomic characteristics of the dictator. ${ }^{20} \mathbf{b}_{\mathbf{4}}^{\prime}$ summarizes the effect of this vector $\mathbf{X} .^{21}$ Session(Mundlak-Chamberlain) is a vector of the average value of donations to all recipients in the session, such that $\mathbf{b}_{\mathbf{5}}^{\prime}$ captures the effect of session-specific characteristics. ${ }^{22}$ RecipientEthnoReligiousID is a vector of controls for the ethno-religious identity of the recipient (relevant only for the analysis of donations to all recipients) and RecipientFace is a vector of

\footnotetext{
${ }^{20}$ The results we present in Table 3 are specifications that control only for Age, the dictator's age, and Previous sessions, whether the dictator knows players who played in previous sessions. In robustness checks, we also control for post-treatment factors, or controls that are endogenous to the player's migration to France, e.g. household income, education, and religiosity.

${ }^{21}$ The notation $\mathbf{b}_{\mathbf{4}}^{\prime}$ is the transpose of $\mathbf{b}_{\mathbf{4}}$, a mathematical requirement for the product of two vectors.

${ }^{22}$ We rely on this Mundlak-Chamberlain device, rather than session fixed effects, which we cannot use in our model.
} 
controls for the face of the recipient (relevant only for the analysis of donations to all recipients and to French recipients, since the analysis of donations to SM/SX recipients already naturally controls for the face of the recipient). We cluster the standard errors at the individual level, since donations from the same player to different recipients cannot be considered as independent from one another. ${ }^{23}$

In table 3, model (1) highlights three results. First, since male SM dictators give less money to both male and female recipients, their differential donations to men and women are not statistically significant (see the p-value for $\Delta_{3}$, model (1)). On the other hand, male SX dictators give more to female recipients than to male recipients, and this difference is statistically significant at least at the $95 \%$ confidence level (see the p-value for $\Delta_{4}$, model (1)). Consequently, the difference-indifference between how SM and SX dictators treat women vs. men is statistically significant at the 90\% confidence level, and this result holds in specifications that include post-treatment controls and that impute missing data.

On average, SM male dictators favor men over women; but in a regression analysis, controlling for the socio-economic status of the dictator, the face and ethno-religious identity of the recipient, and the characteristics of the session, this difference disappears. By contrast, in our regression analysis, SX male dictators significantly favor women over men. In short, given opportunities to be generous in the dictator game, SX men favor women, but SM men do not.

\subsubsection{Finding 2: SX male dictators favor French women over French men, while SM male dictators do not.}

In table 2.B and table 3, model (2), we analyze SX male vs. SM male donations to female and male rooted French recipients. Male SM dictators give on average 0.76 euros to French men, compared to only 0.38 euros to French women. This difference of 0.38 euros, while not statistically significant on its own, is significantly different from the way in which male SX dictators treat French men vs. women (at the 99\% confidence level). Indeed, while male SM dictators tend to

\footnotetext{
${ }^{23}$ We have missing data for our socio-demographic controls. In robustness checks, we impute missing data via multiple imputation analysis in Stata 11.0.
} 
favor rooted French men, male SX dictators significantly (at the 90\% confidence level) favor rooted French women, giving them on average 1 more euro.

In table 3, model (2) corroborates these results. First, male SM dictators give less to French women than to French men, but this difference is not statistically significant (see the p-value for $\Delta_{3}$, model (2)). However, male SX dictators give significantly more to French women than to French men, and this difference is statistically significant at least at the $99 \%$ confidence level (see the p-value for $\Delta_{4}$, model (2)). Finally, the difference between how male SM and SX dictators treat French women vs. men (the difference-in-difference) is significant at least at the $99 \%$ confidence level. These results hold in specifications that include post-treatment controls and that impute missing data. Here, we find confirmation that SX men favor French women, but SM men do not.

\subsubsection{Finding 3: SX male dictators favor their co-ethnic women over their co-ethnic men, while SM male dictators discriminate against their co-ethnic women relative to their co-ethnic men.}

When we turn to gender norms among co-ethnics, a more powerful story delineates itself. Indeed, while SM male dictators do not clearly differentiate between the average male and female recipients, or between male and female rooted French recipients, they do differentiate significantly between co-ethnic male and female recipients. The results in table 2.C and in table 3, model (3) indicate that both SX and SM male dictators differentiate between male and female co-ethnic recipients, but in opposite directions: SX tend to favor their women, while SM tend to favor their men. Table 2.C indicates that male SM dictators give an average 1.33 euros to co-ethnic men compared to only 0.14 euros to co-ethnic women. This difference is statistically significant at the 95\% confidence level. Male SX dictators, on the other hand, give an average 3 euros to co-ethnic women compared to 2 euros to co-ethnic men. We cannot calculate statistical significance due to low power, but we do observe average tendencies that favor women in the case of Christians and that favor men in the case of Muslims.

In table 3, model (3) indicates that male SM dictators give significantly more to co-ethnic men 
than to co-ethnic women, and this is statistically significant at the $99 \%$ confidence level (see the p-value for $\Delta_{3}$, model (3)). The statistical significance of this result holds at least at the $95 \%$ confidence level in specifications that include post-treatment controls and that impute missing data. By contrast, male SX dictators tend to favor female over male co-ethnics, but this difference is not statistically significant in all specifications (the p-value for $\Delta_{4}$, model (3), does not reach significance thresholds in all robustness checks). At the very least, therefore, SX dictators treat their male and female co-ethnics equally. Finally the difference between the way in which male SM dictators treat their women and the way in which male SX dictators treat their women (the difference-in-difference) is statistically significant at least at the $95 \%$ confidence level in all models. Note, however, that this entire analysis relies on very low power: we only have one instance of a male SX dictator donating to a female SX dictator, casting doubt on the stability of our results. We thus take these findings as tentative evidence of co-ethnic gender discrimination on the part of male Muslim dictators.

\subsubsection{Finding 4: SX female dictators treat their co-ethnic men and women on an equal basis, while SM female dictators discriminate against their co-ethnic women relative to their co-ethnic men.}

We next perform a parallel analysis of female dictator behavior on all recipients (table 4.A and table 5, model (1)), on rooted French recipients (table 4.B and table 5, model (2)) and on co-ethnic recipients (table 4.C and table 5, model (3)). Both difference-of-means and regression analyses indicate that female SX and SM dictators do not differ significantly in their behavior toward all recipients and toward rooted French recipients: both tend to give slightly more to women than to men. ${ }^{24}$ But when it comes to intra-group donations, table 4.C and table 5, model (3) uncover a striking result. Indeed, we find that female SX dictators give similarly to female and male coethnics, but that female SM dictators give significantly more to male co-ethnics (1.40 euros on average) than to female co-ethnics (0.33 euros on average). This difference of over 1 euro is

\footnotetext{
${ }^{24}$ We rely on Equation (1) applied to female dictators for our regression analysis.
} 
statistically significant in most specifications. The difference-in-difference between how female SM dictators treat female vs. male co-ethnics, and how female SX dictators treat female vs. male co-ethnics, is statistically significant at least at the $95 \%$ confidence level in almost all regression models. ${ }^{25}$ It is significant at the $99 \%$ confidence level in our difference-of-means analysis. The evidence therefore suggests that female SM dictators disfavor women within their own community.

Our dictator game offers one measure of gender norms among Muslim vs. Christian immigrants to France. It isolates the religious effect via its novel identification strategy, and measures discriminatory behavior toward women via an experimental game with monetary stakes. It therefore resolves two major issues that plague discussions of gender norms among Muslims. Having done so, it confirms that Muslim players (both male and female) are less generous toward women than are matched Christian players. Can this explain Muslim economic underperformance in France?

\section{Testing the correlation between Islam and the channels through which gender norms impact economic performance}

\subsection{Data and research design}

We examine the possible economic consequences of in-group gender norms by testing correlations between the religious identities of our Senegalese players and three possible channels linking gender norms to economic progress: (1) the human capital channel, (2) the bargaining-power channel, and (3) the recruiter channel. We examine these correlations through a variety of methods: we test channels (1) and (2) using a medium-N survey analysis (N=511) of SM and SX households in France in 2009. We test channel (3) using experimental data on the beliefs of rooted French about SM versus SX gender norms, and drawing from an ethnographic account of French recruiting practices (Bouzar and Bouzar (2009)).

\footnotetext{
${ }^{25}$ The significance drops below conventional levels when the model controls for household income and when it imputes missing data.
} 
Our original survey of 511 Serers and Joolas in France, both Christians and Muslims, was administered from April to June 2009 by the professional survey firm Conseils-Sondages-Analyses (CSA). The survey relied on a non-random sample of respondents initially contacted by linking Serer and Joola surnames with cell numbers, ${ }^{26}$ and interviewed by telephone. To increase the sample, and relying on skilled ethnographers who went into targeted neighborhoods, face-to-face interviews were also conducted. The following four eligibility criteria were used: the respondent had to: (1) be 18 to 40 years of age, (2) be born in France, (3) have at least one parent or grandparent born outside of France, and (4) have at least one Serer or Joola-speaking grandparent. Quotas were used to ensure better sample representativeness. Respondents represent $1.2 \%$ of the eligible population-base. This survey data, which we call the CSA data, allows us to test the human capital channel using data on female SM vs. SX educational achievement. It also allows us to test the bargaining power channel using data on rates of participation in the labor force, sex of the first migrant, marriage practices of the first migrant, sex of the head of household, and the respondent's number of children.

We provide indirect evidence as to whether the recruiter channel is at stake through an experiment conducted among rooted French subjects in March 2010. If the economic disadvantage of Muslim immigrants in France is due to French recruiters' reluctance to hire candidates whom they believe abide by Muslim norms that favor men over women, we need a test of rooted French beliefs about Muslim vs. Christian in-group gender norms, controlling for ethnicity. To do this, we recruited 50 rooted French subjects then living in the 19th district of Paris. We contracted CSA to recruit respondents with addresses in the 19th district, and they did so relying on the phone directory. The sample was non-random, since it depended on the agreement of individuals who were called to participate in the experiment, but through quotas on neighborhood (quartier), gender, and age we guarded against systematic bias with respect to critical observable characteristics. ${ }^{27} \mathrm{Re}-$

\footnotetext{
${ }^{26}$ To avoid bias, we did not rely on landlines, as they would tap only the wealthiest, and least typical, of the immigrant population.

${ }^{27}$ To address the possible selection bias, we compare the rooted French players in our 2009 game with rooted French respondents in the nationally-representative European Social Survey (ESS) in 2009. We find, in both difference-of-means and regression analyses, that our sample of rooted
} 
spondents were invited to register if and only if they reported that all four grandparents were born within France's continental boundaries, thereby qualifying as rooted French. The average age of players was 40 , ranging from 20 to 59. Twenty-seven were female, and twenty-three were male.

The games took place in an office building in the nearby 18th district, and were administered by computer, in groups of five. Each player sat in front of a computer without interacting with any of the other four players who were all sitting in front of their monitors. On the computer screen, rooted French players saw pictures of our 2009 Senegalese dictators (whom they had never met and who were the SX and SM players who had participated in our 2009 dictator game); however, we varied their assigned names such that half the rooted French players saw the real name and the other half saw an ascribed name reflecting membership in the other religious group. We asked our 2010 subjects to guess how much each of these 2009 dictators donated to each of the 2009 recipients. Correct guesses were financially rewarded. ${ }^{28}$ This game allows us to compare rooted French guesses about SM vs. SX dictators' generosity toward rooted French women, ${ }^{29}$ holding the face of the person whose donation is guessed constant. Figure 2 provides a sample screenshot.

\subsection{Empirical results}

Tables 6 and 7 test each channel via regression analysis of the CSA survey and experimental data. In Table 6 we present a specification that compares, as it applies, male and female SM vs. SX individuals (models (1) and (2), via the variables Female SM, Male SX, and Female SX) or households (models (3) through (7), via the variables Muslim hh and Female) to examine channel (1), the French in 2009 is more left-wing in political ideology than is the ESS sample of rooted French, suggesting that our sample is more open to diversity than the average rooted French. We do not have a 2010 ESS to conduct such an analysis for our 2010 sample of rooted French players. However, our 2010 sample of rooted French players was recruited from the same district as our 2009 sample, and was presented the games in the exact same manner. It is therefore likely that the direction of the bias in 2010 is the same as the one we found in 2009, and thus that we face a harder test for detecting discrimination or discriminatory beliefs.

${ }^{28}$ Players received 50 centimes for each correct answer. In cases where rooted French had to guess donation amounts for player match-ups that never actually occurred in 2009, they were automatically given 25 centimes.

${ }^{29}$ Our results hold for donations to the average woman. 
human capital channel and channel (2), the bargaining power channel. The specifications in Table 6 include Respondent \& first migrant controls, which are either exogenous or pre-treatment (e.g., before migrating to France) controls: the education of the first migrant, the age of the respondent and the year of arrival in France. In robustness checks, we include controls that are endogenous to being SM or SX in France (household income and religiosity): our results are largely unchanged. In Table 7, we present a specification that compares rooted French beliefs about SM vs. SX dictator donations (captured with the variables $S M \rightarrow$ French female recipient, $S X \rightarrow$ French male recipient, and $S X \rightarrow$ French female recipient), and controls - under Guesser controls - for the sex, age, income, education and religiosity of the rooted French respondent. It also includes recipient, dictator, computer and session fixed effects.

Is gender discrimination consequential for Muslim women's human capital accumulation (channel (1))? Results in Table 6, Model (1) indicate that SM women do not suffer from a lack of human capital relative to SX women. Not only is the difference between female SM and SX education levels never statistically distinguishable from zero (the p-value of the Wald test, not shown here, comparing coefficients (5) and (3) is $p=0.384$ ); the difference-in-difference between female vs. male education levels is not statistically significant either $(p=0.371)$. When it comes to outcomes that matter for economic development, such as education, SX and SM women do not differ. ${ }^{30} 31$

\footnotetext{
${ }^{30}$ Education according to Read and Oselin (2008) is an invalid indicator of economic integration because it is only weakly related to employment. They find that in one Arab-American community, Muslim respondents achieve slightly higher rates of education. However, female Christian respondents were more likely to be employed than their Muslim counterparts, as Muslim women (in the authors' interpretation) relied on advanced education for cultural status rather than economic achievement. This might explain our non-results for the human capital channel.

${ }^{31}$ Attitudinal indicators also yield ambiguous results. On whether respondents differ in educational ambitions for sons vs. daughters, relative to SX women, SM women favor their son's education in both a difference-of-means test and in multivariate regressions (significant at least at the $95 \%$ confidence level). On whether respondents differ in their beliefs that a male vs. a female student should sacrifice his/her career to take care of a sick mother, SM and SX women do not differ, but male SM are less likely than male SX to disapprove of a female student's unwillingness to sacrifice her career. These results hold in both a difference-of-means test and in multivariate regressions (significant at least at the $99 \%$ confidence level). They have no clear interpretation, and underline the complexity of drawing quick conclusions about economic success of Muslims from information about gender norms.
} 
Is gender discrimination consequential for Muslim women's bargaining power (channel (2))? Our analysis in Table 6, Models (2) through (7), provides mixed results. On one hand, SM women are significantly less likely than SX women to be heads of household (a significant result at the $90 \%$ confidence level), ${ }^{32}$ and they have more children than their SX counterparts (a significant result at the $95 \%$ confidence level). On the other hand, SM women are just as likely to participate in the labor force as are SX women (see the p-value of 0.252 for the difference-in-difference in model (2)); SM and SX households are equally likely to have had a woman as the family's first migrant (see model (3), row (1)); and first migrants in SX and SM households were equally likely to practice polygamy (see models (4) and (5), row (1)). ${ }^{33}$ In sum, evidence that SM women suffer from a lack of bargaining power remains ambiguous; there is some indication that SM women have less bargaining power in their households, and some evidence that there is no statistically distinguishable difference.

The behavioral differences uncovered in our analysis of the dictator game do not appear consequential for Muslim women's bargaining power or human capital accumulation. Do Muslims suffer instead from reactionary behavior on the part of French recruiters who do not wish to hire people whose gender norms they believe will hurt the work environment? We know from our CSA data that SM men are significantly less likely, relative to SX men, to favor female over male employment when jobs are scarce. ${ }^{34}$ But do French recruiters perceive SM in-group norms disfavoring women and condition their hiring decisions on it? We test the beliefs of rooted French

\footnotetext{
${ }^{32}$ A difference-of-means test also yields a significant result: Muslim households are significantly less likely to have a female head-of-household than are Christian households $(24.22 \%$ vs. $47.66 \%$, a difference that is statistically significant at the $99.99 \%$ confidence level). Yet, it is possible to interpret the head of household variable - not at all as an indicator of bargaining-power in the household - but rather as an indicator that the husband has left or passed away.

${ }^{33}$ Attitudinal indicators yield similarly ambiguous results. SM women are more likely than SX women to disapprove of a daughter marrying a religious-other, but SX men are more likely than SM men to disapprove of a daughter marrying a religious-other (both results are fragile). Finally, respondents were asked whether they believe that women are made to rear and raise children first. SM and SX men's responses did not differ significantly. SM women, however, were more likely to agree with the statement than were SX women; this difference is significant at the $95 \%$ confidence level.

${ }^{34}$ Analysis tables are not presented here but are available upon request.
} 
players about these norms using data from our 2010 experiments, and present our analysis in Table 7. Model (1) displays results from our analysis of French beliefs about male dictator donations. These results indicate that French respondents in 2010 believed that male SX dictators would be more generous toward French female recipients than toward French male recipients, and this result is statistically significant at the $99 \%$ confidence level (the p-value of the difference between coefficients (2) and (3), not shown here, is $p=0.000$ ). However, French respondents in our 2010 experiments also believed that male SM dictators would be more generous toward French female recipients than toward French male recipients, and this result is also statistically significant at the $99 \%$ confidence level (the $\mathrm{p}$-value for coefficient (1) in column (1) is $p=0.009) .{ }^{35}$ The differencein-difference is thus not significant $(p=0.680)$.

Similarly, Model (2) displays results from our analysis of French beliefs about female dictator donations. These results indicate that French respondents in 2010 believed that female SX dictators would be more generous toward French female recipients than toward French male recipients, and this result is statistically significant at the $95 \%$ confidence level (the p-value for the difference between coefficients (3) and (2), not shown here, is $p=0.027)$. However, French respondents also believed that female SM dictators would be more generous toward French female recipients than toward French male recipients, and this result is statistically significant at the $90 \%$ confidence level (the p-value for coefficient (1) in column (2) is $p=0.058){ }^{36}$ The difference-in-difference is, again, not significant $(p=0.946)$. We therefore have no evidence that rooted French perceive different gender norms among SM and SX who share the same nationality and ethnicity.

While the experimental evidence allows us to detect causal effects between religion and ingroup gender norms, it does not provide a direct test of French recruiter beliefs. Rather, it relies on the beliefs of a sample of rooted French from the 19th district of Paris. We therefore complement our experimental test of channel (3) with a report on a sociological analysis of the relationship of Muslim employees to managers and co-workers in large French firms. Bouzar and Bouzar (2009)

\footnotetext{
${ }^{35}$ These results are confirmed by difference-of-means tests.

${ }^{36}$ These results are corroborated by difference-of-means tests although statistical significance does not reach conventional levels here.
} 
rely on interviews with human resources managers to show that H.R. personnel condition their hiring decisions on their beliefs about what Muslims will do to the esprit-de-corps of their work teams. They report egregious behavior of Muslim male employees toward both rooted French women and Muslim women in the workplace. For example, one manager recounts an incident during the month of Ramadan involving a young Muslim man and a young Muslim woman. The young Muslim man was fasting in observance of Ramadan while the young Muslim woman was not. The young man verbally assaulted his female co-worker when she brought a hot chocolate back to her desk, accusing her of disrespect by drinking in front of him. Other examples abound: one French manager reported a Muslim male employee harassing his female colleagues who, he believed, wore inappropriate clothes.

The Bouzar and Bouzar (2009) study is important because it interviews directly those who make hiring decisions on the French labor market: H.R recruiters. It provides qualitative evidence in support for channel (3); but we cannot rule out the possibility that these interviews represent post-facto rationalizations for prejudicial behavior, perhaps based on popular scripts about Islam coming from the media. Taken together, the experimental and sociological evidence offer ambiguous support for channel (3), and highlight the need for experimental evidence identifying the beliefs of French H.R. recruiters about Muslim vs. Christian gender norms.

Table 8 summarizes the survey and experimental findings for each of the three channels we test here. It shows that we find at best inconsistent support for any of the three channels that might link Muslims' gender discrimination to their economic disadvantage in France.

\section{Discussion}

Our empirical approach is two-fold. In a first test, we are able to identify differences between SM and SX gender norms. In a second test, we examine correlations between SM (SX) and the possible channels linking gender norms to economic progress. These correlations allow us to explore a range of factors revealing that in the real world, all other things are rarely equal. However, lacking 
an identification strategy, these tests do not permit causal claims. Tests of channels (1) and (2), for example, rely on observational data and thus cannot identify a causal effect. The test of channel (3) is experimental, but focuses on a quota sample of rooted French participants rather than French recruiters. Therefore, the research design cannot reject a causal relationship between the identified gender norms and Muslims' lapsed economic integration in France.

The failure to identify significant correlations comes from two possible sources. First, channels (1) and (2) are at play, but intervening factors mitigate the effects of human capital accumulation and bargaining-power on economic progress. Second, channel (3) is at play, but our sample of rooted French in March 2010 is systematically different from French recruiters; a test of French recruiter beliefs about SM and SX gender norms is thus needed. In this section, we consider a few examples of omitted variables that might explain our non-results for channels (1) and (2).

Muslims face significant discrimination on the French labor market. As we emphasized in the introduction, Adida, Laitin, and Valfort (2010) rely on a correspondence test to show that a SM job candidate is 2.5 times less likely to receive a call-back for an interview than is an identical SX job candidate. ${ }^{37}$ Muslim households may, in an attempt to counteract such discrimination, put as many household members as possible to work in order to make a living. In the face of discrimination, Muslim households may counter their own gender norms to improve their livelihoods, thereby preventing us from finding empirical support for the bargaining power channel.

Alternatively, Muslim gender norms may incentivize Muslim women to catch up through perseverance, patience, and cultural skills that matter for educational achievement. This would prevent us from finding empirical support for the human capital channel. In a comprehensive sociological study of immigrant cultures in the sensitive neighborhoods surrounding France's major cities, Lagrange (2010) confirms that patriarchy exists among (mostly Muslim) immigrant families from the Sahel (Lagrange (2010): 25, 189-91). However, this patriarchy does not imply a failure of girls to outpace boys in school. In fact, in the schools in the sensitive districts surrounding Paris, the girls far outpace the boys in educational success at an early age. This is due precisely to the

\footnotetext{
${ }^{37}$ The only differences between the two candidate CVs are several signs designating religious affiliation.
} 
restrictions on girls compared to the freedom for boys in these neighborhoods. It is in the schools that girls find relative freedom to hang out with friends, and the promise of emancipation; as a result, girls enjoy being in school. By contrast, among these patriarchal families, fathers failed when they abided by the rules; their sons have therefore not associated schooling with opportunity. To the extent this patriarchy is more prevalent in Muslim families, we see how disempowerment of women in the neighborhoods is associated with empowerment of girls in the schools (Lagrange (2010): 202-209).

Finally, institutional factors in the host country might counteract the effect of Muslim gender norms. In France, for example, education is compulsory and there are very few Islamic schools. ${ }^{38}$ Compulsory education, therefore, may counteract the effect of Muslim gender norms on economic progress and prevent us from finding empirical support for the human capital channel.

In sum, the absence of significant correlations between being Muslim (Christian) and the channels through which gender norms yield economic progress does not necessarily mean that Muslim gender norms do not hurt Muslim economic progress. Instead, it points to a much more complex relationship between gender norms and economic integration among Muslims than today's conventional wisdom will have us believe.

\section{Methodological concerns}

Our analysis brings empirical scrutiny to the conventional wisdom about Muslim gender norms and Muslim economic performance. Its results question the conventional wisdom. At the same time, a number of methodological concerns remain.

\footnotetext{
${ }^{38}$ See Fetzer and Soper (2005), who highlight that "metropolitan France contains not a single state-funded Islamic school... [and only] a handful of privately funded Islamic schools." (pp. 8586).
} 


\subsection{Is our measure of discrimination valid?}

Why do we observe discrimination in a laboratory setting that appears to be inconsequential in the real world? One explanation is that the differential donations we observe in our dictator game do not measure gender discrimination because they capture only one dimension of a broader bargaining story between Muslim men and women. Senegalese Muslims might prefer to support women through alternative channels (for example, by keeping the money they earn in our laboratory games and taking it home to their wives); if that is the case, the differential donations we observe in the game capture only one aspect of gender relations among Muslims. This bargaining story might be a compelling explanation if we observe, in the experiment, discrimination of Muslims only toward Muslim women. However, what we find is a pervasive lack of generosity toward all women on the part of Muslims. When given the opportunity to donate to the average female recipient, or to rooted French female recipients, Muslims continue to refrain themselves. Our experiments are thus capturing a phenomenon that cannot be explained merely by intra-group gender bargains.

\subsection{External validity}

In this section, we consider two possible problems with external validity: the fact that our sample of migrant SM and SX may be systematically different from those who stayed in Senegal; and the fact that we focus on Senegalese Muslims in France rather than North African Muslims, who constitute the large majority of the immigrant Muslim community in France.

First, we consider whether the migrating Senegalese Muslim community is significantly different from that which did not migrate, such that the differences we observe in our dictator game are driven by unique characteristics of the Senegalese Muslim population sampled. We address this source of bias by turning to behavioral indicators of gender discrimination in Senegal using Afrobarometer data from Senegal. We merge data from all three rounds (2002, 2005 and 2008), and focus on a sub-sample of Christian and Muslim respondents from the Joola and Serer language communities. These data allow us to measure behavior by focusing on three questions that were common to all three rounds: the interviewer's assessment of whether the respondent's spouse was 
present during the interview (Spouse present); the interviewer's assessment as to whether the respondent summoned others to answer questions (Summoned others); and the interviewer's assessment of the probability that the respondent was influenced by others in her responses (Influenced by other). Table 9 presents results from a regression analysis that compares SM and SX male and female respondents (via the variables Female SM respondent, Male SX respondent, and Female SX respondent), and includes fixed effects for each of the Afrobarometer rounds (Year fixed effects); socio-demographic controls of the respondent and the household (Respondent controls); and sociodemographic controls of the interviewer (Interviewer controls). Standard errors are clustered at the regional level.

Our results show that what we observed in the laboratory in Paris is compatible with what Afrobarometer surveyors reported in Senegal. Specifically, Table 9, column (3) indicates that female SM are more likely to have been influenced by others during their interview than are female SX: the difference-in-difference is statistically significant at the $99 \%$ confidence level $(p=0.01) .{ }^{39}$ These results hold controlling for the Afrobarometer round (the year fixed effects), and apply specifically to Senegalese Joola and Serer, Muslim and Christian respondents in Senegal. ${ }^{40}$ They raise doubt about claims that those SM who migrated to France are systematically different, at least with regard to gender norms, from those who stayed in Senegal.

Second, SM migrants might systematically differ from other Muslims in France, in such a way

${ }^{39}$ Results hold in a logit specification. Furthermore, difference-of-means analyses (not presented here) indicate that SM women were more likely than SX women to have a spouse present and to have been influenced by someone during the interview (statistically significant differences at least at the $95 \%$ confidence level).

${ }^{40} \mathrm{We}$ also find some evidence that migration exacerbates these gender norms. In the CSA survey, SX men with longer family histories are less likely to agree with the claim that women are made to rear children first and foremost (relative to SX men with shorter family histories), than are SM men with longer family histories (relative to SM men with shorter family histories). We propose that the migration process exacerbates norms of gender discrimination through two possible mechanisms. First, SM in France constitute a double minority: they are Senegalese and Muslim in a Christianheritage country. By contrast, SX in France are a single minority. Does this double-minority status exacerbate norms that differentiate Senegalese Muslims from their hosts? Second, following the work of Waters (1999) in the United States, SM and SX could associate with differently-placed status groups in their host country; such associations could reinforce the norms we observe. 
that prevents us from generalizing about Muslim immigrants to France. In what direction might our reliance on SM - rather than North African Muslims - bias our results? Recall first that our reliance on Senegalese Muslims, rather than North African Muslims, is precisely what enables us to identify a Muslim effect, controlling for country-of-origin and ethnicity. Indeed, in the tradeoff between external and internal validity, this paper prioritizes internal validity and identifies the causal effects of religion. Furthermore, according to Diop (1988), the French population associates Black African Muslims less readily with Islam than they do North African Muslims, because Black African Muslims speak little to no Arabic and interact indiscriminately with African Muslims and African non-Muslims (Adida, Laitin, and Valfort (2010)). If true, this pattern might explain our non-results for channel (3): since the Muslim effect for Senegalese would be attenuated (and thus the lower bound of the general Muslim effect), rooted French may not perceive our SM players to be more heavily influenced by discriminating gender norms than our SX players as much as they would for Maghrebi Muslims as compared to say European Christian migrants. Additionally, human-resource recruiters in France probably have better knowledge of minority-group characteristics than do our French players. These factors suggest that our test probably underestimates the beliefs of French recruiters about Muslim gender norms: consequently, we cannot yet rule out channel (3), i.e. the recruiter channel.

\subsection{The distribution of donations}

Finally, we ask whether the differences in donations to women between SM and SX dictators are driven by different central tendencies or by different tails in the overall distribution of donations. In other words, are these differences driven by a plurality of players or by a few outliers? Each entails different policy implications. Suppose discrimination reflects a central tendency. Then the policy implication is to attack the sources of that discrimination to compel an average change in behavior by the discriminating group. However, if the discrimination reflects only the tails of the distribution, the policy implication should be to redesign institutions to empower the median group 
actor at the expense of those at the extremes. ${ }^{41}$

Are the differential donations identified in our dictator game driven by differences in average behavior between Muslims and Christians, or by outliers on two different ends of the distribution tail? Figures 3 and 4 illustrate the distribution of the dictator-donation amounts for female and male SM and SX dictators toward all female recipients. Kolmogorov-Smirnov equality-of-distribution tests indicate that the distributions are not equal in both cases (at the $90 \%$ confidence level for female Muslims vs. Christians and at the $99 \%$ confidence level for male Muslims vs. Christians ${ }^{42}$ ); but the graphical distribution of the variable confirms that modal values are systematically higher for Christians than for Muslims. The modal Muslim female dictator gives 1 euro to female recipients, while the modal Christian female dictator gives 2 euros to female recipients. Similarly, the modal Muslim male dictator gives 0 euro to female recipients, compared to 2 euros for the modal Christian male dictator. ${ }^{43}$ Gender discrimination among Muslims does not appear to be driven by a few outliers. The modal SM gives less to women than does the modal SX. ${ }^{44}$

\footnotetext{
${ }^{41}$ The following analogy might be useful. Research on American voters reveals that they are on average moderate (Fiorina 2004). However, those at the extremes have extraordinary sway in the election of representatives. If the tail is wagging the dog, there is no payoff in seeking to moderate the average voter. Rather, an institutional intervention, such as mandatory primary voting, would decrease the influence of the extreme voters, assuming that the radicals vote more persistently in the primaries than do the moderates.

${ }^{42}$ We rely on the exact $p$-value.

${ }^{43}$ Figure 4 raises a question: if a plurality of male Senegalese Muslims gives 0 , could our results be driven by the presence of players who never discriminate? ((Habyarimana et al. 2007) call these non-egoists.) Our difference-in-difference analysis gets around this problem: even if Senegalese Muslims are simply more "egoistic", these player-types continue to discriminate between female and male recipients. Furthermore, we run our analysis with a control for egoism (measured as (Habyarimana et al. 2007) do, and included in the specifications in table (3)). Our results are unchanged.

${ }^{44}$ Figures 3 and 4 show just how little money was given in this dictator game. This differs from dictator games executed elsewhere, where averages are systematically higher. We propose that this may be due to the fact that our player pool is a group of Senegalese immigrants to France, a minority that is probably less secure on a number of dimensions. More work should explore how dictator donations change when dictators switch from majority to minority status.
} 


\section{Conclusion}

This paper has identified a conventional wisdom that explains Muslim economic underperformance with Muslim gender norms, and typified it with the following syllogism: (1) the empowerment of women is a sine qua non for full-fledged economic progress; (2) in-group norms among Muslims do not empower women to the degree to which in-group norms among non-Muslims do; and hence (3) Muslim communities will underperform economically relative to non-Muslim communities. Relying on a matching strategy between two Senegalese language communities that are split by religion but otherwise similar, this paper has identified differing gender norms between Muslims and Christians in the context of a dictator game in France: ceteris paribus, the logic of this syllogism holds. And yet, using survey data based on the same matching strategy, this paper has found no consistently significant correlation between religious identity and the channels linking gender norms to economic progress. Muslim women are no less educated than matched Christian women; they are not unambiguously less empowered in their households either; and rooted French do not associate our Senegalese Muslim players with different gender norms relative to our Senegalese Christian players. In the real world, which is not ceteris paribus, the syllogism breaks down.

In sum, this paper combines experimental data allowing for the causal identification of religion and gender norms, with observational data reminding us that - in the real world - countless confounds can mitigate a ceteris paribus relationship. By doing so, it urges a change in public discourse to reflect the skepticism our systematic analysis brings. Furthermore, it calls on future research to offer more direct tests of the possible linkages between Muslim gender norms and Muslims' lapsed economic integration. Specifically, a direct test of French recruiter beliefs about Muslim gender norms seems like the natural next step in this research agenda.

Future research should also extend these results to other matched samples throughout Europe to provide a clear sense of the magnitude of the problem, and to develop better tests on the beliefs of rooted majorities in Europe about the likely behaviors of Muslim applicants. The question of Muslim integration into Europe, and the gender issues that surround it, are too important to allow either prejudice or denial to reign. 


\section{References}

Abu-Ghaida, D. and S. Klasen (2004). The costs of missing the millenium development goal on gender equity. World Development 32(7), 1075-1107.

Adida, C. L., D. D. Laitin, and M. A. Valfort (2010). Identifying barriers to Muslim integration in France. Proceedings of the National Academy of Sciences 107(52).

Adida, C. L., D. D. Laitin, and M. A. Valfort (2012, January). One Muslim is enough! Evidence from a field experiment in France. Working Paper.

Alexander, A. C. and C. Welzel (2011, April). How robust is Muslim support for patriarchal values? A cross-national multi-level study. Technical report, Center for the Study of Democracy, U.C. Irvine.

Atkin, D. (2009). Working for the future: female factory work and child health in Mexico. Unpublished Manuscript, Yale University.

Blaydes, L. and D. A. Linzer (2008, July). The political economy of women's support for fundamentalist Islam. World Politics 60, 576-609.

Bleich, E. (Ed.) (2009). Muslims and the State in the Post-9/11 West. Routledge.

Boone, P. (1996). Political and gender oppression as a cause of poverty. LSE Centre for Economic Performance Discussion Paper No. 294.

Bouzar, D. and L. Bouzar (2009). Allah a-t-il sa place dans l'entreprise? Paris, France: Albin Michel.

Bowen, J. (2007). Why the French don't like headscarves. Princeton, New Jersey: Princeton University Press.

Breierova, L. and E. Duflo (2004). The impact of education on fertilicty and child mortality: do fathers really matter less than mothers? NBER Working Paper No. 10513. 
Caldwell, C. (2009). Reflections on the Revolution in Europe: Immigration, Islam, and the West. Doubleday.

Camerer, C. F. (2003). Behavioral game theory. Princeton: Princeton University Press.

Carvalho, J.-P. (2011). Veiling. University of California, Irvine. Working Paper.

Case, A. and A. Deaton (1998). Large cash transfers to the elderly in South Africa. The Economic Journal 108(450), 1330-1361.

Chou, Liu, Grossman, and Joyce (2010). Parental education and child health: evidence from a natural experiment in Taiwan. American Economic Journal: Applied Economics 2(1), 33-61.

Delavande, A. and B. Zafar (2011, October). Gender discrimination and social identity: experimental evidence from urban Pakistan. Working Paper.

Diop, A. (1988). Stéréotypes et stratégies. In R. Leveau and G. Kepel (Eds.), Les Musulmans dans la Société Française, pp. 77-98. Paris: Presses de la Fondation Nationale des SciencesPolitiques.

Doepke, M. and M. Tertilt (2010, June). Does female empowerment promote economic development? Working Paper.

Dollar, D. and R. Gatti (1999). Gender inequality, income and growth: are good times good for women? Policy Research Report on Gender and Development Working Paper No. 1, The World Bank.

Doss, C. (2006). The effects of intrahousehold property ownership on expenditure patterns in Ghana. Journal of African Economies 15(1), 149-180.

Duflo, E. (2000, May). Child health and household resources in South Africa: evidence from the old age pension program. The American Economic Review 90(2), 393-398. 
Duflo, E. (2003). Grandmothers and granddaughters: old-age pensions and intrahousehold allocation in South Africa. World Bank Economic Review 17(1), 1-25.

Duflo, E. (2011, November). Women empowerment and economic development. Working Paper.

Duflo, E. and C. Udry (2004, May). Intrahousehold resource allocation in Côte d'Ivoire: social norms, separate accounts and consumption choices. NBER Working Paper 10498.

Fetzer, J. S. and J. C. Soper (2005). Muslims and the State in Britain, France and Germany. Cambridge University Press.

Fiorina, M. P. (2004). Culture War? The myth of a polarized America. Longman.

Fish, M. S. (2011). Are Muslims distinctive? A look at the evidence. Oxford University Press.

Forbes, K. (2000). A reassessment of the relationship between inequality and growth. American Economic Review 90, 869-887.

Gitter, S. R. and B. L. Barham (2008, May). Women's power, conditional cash transfers, and schooling in Nicaragua. World Bank Economic Review 22(2), 271-290.

Habyarimana, J., M. Humphreys, D. N. Posner, and J. M. Weinstein (2007, November). Why does ethnic diversity undermine public goods provision? American Political Science Review 101(4), 709-725.

Hajj, M. and U. Panizza (2009). Religion and education gender gap: are Muslims different? Economics of Education Review 28, 337-344.

Hill, M. and E. King (1995). Women's education in developing countries: barriers, benefits and policies. Baltimore, MD: The Johns Hopkins University Press.

Hoddinott, J. and L. Haddad (1995). Does female income share influence household expenditures? Evidence from Côte d'Ivoire. Oxford Bulletin of Economics and Statistics 57(1), 77-96. 
Howard, M. M. (2009). The Politics of Citizenship in Europe. Cambridge: Cambridge University Press.

Huntington, S. P. (1993, Summer). The clash of civilizations? Foreign Affairs 72(3).

Inglehart, R. (Ed.) (2003). Human values and social change: findings from the Values Surveys. Leiden: Brill.

Kahneman, D., J. L. Knetsch, and R. H. Thaler (1986). Fairness and the assumptions of economics. The Journal of Business 59(4), 285-300.

Kakpo, N. (2007). L'Islam, un recours pour les jeunes. Paris: Presses de la Fondation Nationale des Sciences-Politiques.

Kennedy, E. and P. Peters (1992, August). Household food security and child nutrition: the interaction of income and gender of household head. World Development 20(8), 1077-1085.

King, E. M. and M. A. Hill (Eds.) (1993). Women's education in developing countries; barriers, benefits, and policies. Washington, D.C.: The Johns Hopkins University Press.

Klasen, S. (2002). Low schooling for girls, slower growth for all? Cross-country evidence on the effect of gender inequality in education on economic development. World Bank Economic Review 16(3), 345-373.

Klasen, S. and F. Lamanna (2003). The impact of gender inequality in education and employment on economic growth in the Middle East and North Africa. Mimeographed, University of Munich.

Klausen, J. (2009). The cartoons that shook the world. Yale University Press.

Knowles, S., P. Lorgelly, and P. Owen (2002). Are educational gender gaps a brake on economic development? Some cross-country empirical evidence. Oxford Economic Papers 54, 118-149.

Lagrange, H. (2010). Le déni des cultures. Paris, France: Seuil. 
Lawrence, J. and J. Vaisse (2006). Integration Islam: political and religious challenges in contemporary France. Washington, D.C.: Brookings Institute Press.

Lundberg, S. J., R. A. Pollack, and T. J. Wales (1997). Do husbands and wives pool their resources? Evidence from the United Kingdom Child Benefit. The Journal of Human Resources 32(3), 463-480.

Mernissi, F. (1987). Beyond the veil: male-female dynamics in modern Muslim society. Indiana University Press.

Meyersson, E. (2011, March). Islamic rule and the emancipation of the poor and pious. Sciences Po Working Paper.

Phipps, S. A. and P. S. Burton (1998). What's mine is yours? The influence of male and female incomes on patterns of household expenditure. Economica 65(260), 599-613.

Pitt, M. M. and S. R. Khandker (1998, October). The impact of group-based credit programs on poor households in Bangladesh: does the gender of participants matter? Journal of Political Economy 106(5), 958-996.

Read and Oselin (2008, April). Gender and the education-employment paradox in ethnic and religious contexts: the case of Arab Americans. American Sociological Review 73, 296-313.

Read, J. G. (2004, November). Family, religion and work among Arab American women. Journal of Marriage and Family 66, 1042-1050.

Ross, M. (2008). Oil, Islam, and Women. American Political Science Review 102(1).

Sharabi, H. (1988). Neopatriarchy: a theory of distorted change in Arab society. New York: Oxford University Press.

Sniderman, P. and L. Hagendoorn (2007). When ways of life collide. Princeton University Press.

The World Bank (2001). Engendered development. Technical report, The World Bank, New York. 
The World Bank (2011). World development report 2012: Gender equality and development. Technical report, The World Bank, Washington, D.C.

Thomas, D. (1990). Intra-household resource allocation: an inferential approach. The Journal of Human Resources 25(4), 635-664.

Tilak, J. B. G. (Ed.) (2003). Education, society, and development: national and international perspectives. New Delhi: National Institute of Educational Planning and Administration.

Waters, M. C. (1999). Black identities. West Indian immigrant dreams and American realities. Harvard University Press.

Yamarak, S. and S. Ghosh (2003). Is female education productive? Mimeographed, Medford, MA: Tufts University. 


\section{Tables and Figures}

Table 1: Summary statistics for SM and SX respondents in March 2009

\begin{tabular}{|c|c|c|c|}
\hline Variable & SM & SX & Difference \\
\hline Female & $\begin{array}{c}0.44 \\
(\mathrm{~N}=18)\end{array}$ & $\begin{array}{c}0.55 \\
(\mathrm{~N}=11)\end{array}$ & -0.10 \\
\hline Age & $\begin{array}{c}33.56 \\
(\mathrm{~N}=18)\end{array}$ & $\begin{array}{c}31.45 \\
(\mathrm{~N}=11)\end{array}$ & 2.10 \\
\hline Education & $\begin{array}{c}7.59 \\
(\mathrm{~N}=17) \\
\end{array}$ & $\begin{array}{c}7.63 \\
(\mathrm{~N}=8)\end{array}$ & -0.04 \\
\hline Religiosity & $\begin{array}{c}2.71 \\
(\mathrm{~N}=17)\end{array}$ & $\begin{array}{c}4.9 \\
(\mathrm{~N}=10)\end{array}$ & $-2.19 * *$ \\
\hline Political ideology & $\begin{array}{c}4.73 \\
(\mathrm{~N}=15)\end{array}$ & $\begin{array}{c}4.43 \\
(\mathrm{~N}=7)\end{array}$ & 0.30 \\
\hline Born in France & $\begin{array}{c}0.06 \\
(\mathrm{~N}=18)\end{array}$ & $\begin{array}{c}0.09 \\
(\mathrm{~N}=11)\end{array}$ & -0.03 \\
\hline Family income & $\begin{array}{c}3.87 \\
(\mathrm{~N}=15)\end{array}$ & $\begin{array}{c}4 \\
(\mathrm{~N}=9)\end{array}$ & -0.13 \\
\hline French national & $\begin{array}{c}0.17 \\
(\mathrm{~N}=18)\end{array}$ & $\begin{array}{c}0.18 \\
(\mathrm{~N}=11)\end{array}$ & -0.01 \\
\hline Total N & 18 & 11 & \\
\hline
\end{tabular}

Notes: The table reports arithmetic means for the sub-samples of SM and SX players, and two-tailed t-tests assuming unequal variances. "Female" is a dummy variable that takes the value 1 if the individual is female, and 0 otherwise. "Age" is equal to the age of the individual. "Education" is a categorical variable ranging from 1 (less than primary school completed) to 10 (higher than college degree completed). "Religiosity" is a categorical variable ranging from 1 (never attends religious services) to 7 (attends religious services several times a week). "Political ideology" is a categorical variable ranging from 1 (most left-wing) to 10 (most right-wing). "Born in France" is a dummy variable that takes the value 1 if the individual is born in France, and 0 otherwise. "Family income" is a categorical variable ranging from 1 (less than 500 euros a month) to 11 (more than 7500 euros a month). "French national" is a dummy variable that takes the value 1 if the individual is a French national, and 0 otherwise. $*$ and $* *$ indicate statistical significance at the 5 and $1 \%$ levels, respectively. 
Table 2: Male SM and SX donations to female recipients, difference-of-means analysis

(A) Donations of male SM and SX dictators to all recipients

\begin{tabular}{c|c|c|c}
\hline & $\begin{array}{c}\text { Muslim Dictator } \\
\text { (a) }\end{array}$ & $\begin{array}{c}\text { Christian Dictator } \\
\text { (b) }\end{array}$ & $\begin{array}{c}\text { Difference } \\
(\mathrm{b}-\mathrm{a})\end{array}$ \\
\hline All female recipients & 0.27 & 1.67 & $\Delta_{1}=+1.40$ \\
$(\mathrm{c})$ & $(\mathrm{N}=30)$ & $(\mathrm{N}=15)$ & $\mathrm{p}=0.00$ \\
\hline All male recipients & 0.70 & 1.53 & $\Delta_{2}=+0.83$ \\
$(\mathrm{~d})$ & $(\mathrm{N}=30)$ & $(\mathrm{N}=15)$ & $\mathrm{p}=0.03$ \\
\hline Difference & $\Delta_{3}=+0.43$ & $\Delta_{4}=-0.13$ & Diff-in-Diff: \\
$(\mathrm{d}-\mathrm{c})$ & $\mathrm{p}=0.06$ & $\mathrm{p}=0.75$ & Sig. at 99\% \\
\hline
\end{tabular}

(B) Donations of male SM and SX dictators to rooted French recipients

\begin{tabular}{c|c|c|c}
\hline & $\begin{array}{c}\text { Muslim Dictator } \\
(\mathrm{a})\end{array}$ & $\begin{array}{c}\text { Christian Dictator } \\
(\mathrm{b})\end{array}$ & $\begin{array}{c}\text { Difference } \\
(\mathrm{b}-\mathrm{a})\end{array}$ \\
\hline French female recipients & 0.38 & 2.00 & $\Delta_{1}=+1.62$ \\
$(\mathrm{c})$ & $(\mathrm{N}=13)$ & $(\mathrm{N}=6)$ & $\mathrm{p}=0.00$ \\
\hline French male recipients & 0.76 & 1.00 & $\Delta_{2}=+0.24$ \\
$(\mathrm{~d})$ & $(\mathrm{N}=17)$ & $(\mathrm{N}=9)$ & $\mathrm{p}=0.57$ \\
\hline Difference & $\Delta_{3}=+0.38$ & $\Delta_{4}=-1.00$ & Diff-in-Diff: \\
$(\mathrm{d}-\mathrm{c})$ & $\mathrm{p}=0.28$ & $\mathrm{p}=0.06$ & Sig. at 99\% \\
\hline
\end{tabular}

(C) Donations of male SM and SX dictators to coethnic recipients

\begin{tabular}{c|c|c|c}
\hline & $\begin{array}{c}\text { Muslim Dictator } \\
(\mathrm{a})\end{array}$ & $\begin{array}{c}\text { Christian Dictator } \\
(\mathrm{b})\end{array}$ & $\begin{array}{c}\text { Difference } \\
(\mathrm{b}-\mathrm{a})\end{array}$ \\
\hline $\begin{array}{c}\text { Coethnic female recipients } \\
\text { (c) }\end{array}$ & 0.14 & 3.00 & $\Delta_{1}=+2.86$ \\
$(\mathrm{~N}=7)$ & $(\mathrm{N}=1)$ & $\mathrm{p}=$ Not available \\
\hline Coethnic male recipients & 1.33 & 2.00 & $\Delta_{2}=+0.67$ \\
$(\mathrm{~d})$ & $(\mathrm{N}=3)$ & $(\mathrm{N}=4)$ & $\mathrm{p}=0.44$ \\
\hline Difference & $\Delta_{3}=+1.19$ & $\Delta_{4}=-1.00$ & Diff-in-Diff: \\
$(\mathrm{d}-\mathrm{c})$ & $\mathrm{p}=0.05$ & $\mathrm{p}=$ Not available & Not available \\
\hline
\end{tabular}


Table 3: Regression analysis of male SM and SX dictator donations

\begin{tabular}{|c|c|c|c|c|c|c|}
\hline & \multicolumn{2}{|c|}{$\begin{array}{l}\text { Model (1) } \\
\text { Donations to all women }\end{array}$} & \multicolumn{2}{|c|}{$\begin{array}{c}\text { Model (2) } \\
\text { Donations to French women }\end{array}$} & \multicolumn{2}{|c|}{$\begin{array}{l}\text { Model (3) } \\
\text { Donations to coethnic women }\end{array}$} \\
\hline & Coeff. & SE & Coeff. & $\mathrm{SE}$ & Coeff. & SE \\
\hline (1) $\mathrm{SM} \rightarrow$ FemaleRecipient & -0.183 & $(0.306)$ & -0.011 & $(0.416)$ & $-1.763 * *$ & $(0.594)$ \\
\hline (2) SX $\rightarrow$ MaleRecipient & 0.852 & $(0.461)$ & 0.133 & $(0.513)$ & 0.417 & $(0.619)$ \\
\hline (3) $\mathrm{SX} \rightarrow$ FemaleRecipient & $1.211^{*}$ & $(0.472)$ & 1.549 & $(0.765)$ & $1.458 * *$ & $(0.440)$ \\
\hline (4) Age & 0.004 & $(0.015)$ & -0.005 & $(0.019)$ & 0.033 & $(0.018)$ \\
\hline (5) Previous sessions & -0.263 & $(0.291)$ & -0.165 & $(0.316)$ & 0.536 & $(0.447)$ \\
\hline P-value: $\Delta_{1}=(3)-(1)=0$ & \multicolumn{2}{|c|}{0.01} & \multicolumn{2}{|r|}{0.01} & \multicolumn{2}{|c|}{0.00} \\
\hline P-value: $\Delta_{2}=(2)=0$ & \multicolumn{2}{|c|}{0.09} & \multicolumn{2}{|r|}{0.80} & \multicolumn{2}{|c|}{0.51} \\
\hline P-value: $\Delta_{3}=-(1)=0$ & \multicolumn{2}{|c|}{0.56} & \multicolumn{2}{|r|}{0.98} & \multicolumn{2}{|c|}{0.01} \\
\hline P-value: $\Delta_{4}=(2)-(3)=0$ & \multicolumn{2}{|c|}{0.02} & \multicolumn{2}{|r|}{0.00} & \multicolumn{2}{|c|}{0.05} \\
\hline P-value: Diff-in-Diff $=0$ & \multicolumn{2}{|c|}{0.09} & \multicolumn{2}{|r|}{0.00} & \multicolumn{2}{|c|}{$\mathbf{0 . 0 0}$} \\
\hline Session (Mundlak-Chamberlain) & \multicolumn{2}{|c|}{ Yes } & \multicolumn{2}{|r|}{ Yes } & \multicolumn{2}{|c|}{ Yes } \\
\hline Recipient Ethno-religious identity & \multicolumn{2}{|c|}{ Yes } & \multicolumn{2}{|r|}{ N/A } & \multicolumn{2}{|c|}{ N/A } \\
\hline Recipient face & \multicolumn{2}{|c|}{ Yes } & \multicolumn{2}{|r|}{ Yes } & \multicolumn{2}{|c|}{ N/A } \\
\hline$R^{2}$ & \multicolumn{2}{|c|}{0.380} & \multicolumn{2}{|r|}{0.452} & \multicolumn{2}{|c|}{0.778} \\
\hline Observations & \multicolumn{2}{|c|}{90} & \multicolumn{2}{|r|}{45} & \multicolumn{2}{|c|}{15} \\
\hline
\end{tabular}

Notes: The table reports OLS estimates. The unit of observation is a dyad comprising of a SM or SX male dictator and one of the six recipients. The dependent variable is categorical, ranging from 0 (the dictator gives nothing to the recipient) to 5 (the dictator gives his total endowment to the recipient). In Model (1), the dependent variable is the donation to all recipients. In Model (2), it is the donation to French recipients. In Model (3), it is the donation to coethnic recipients. "SM $\rightarrow$ FemaleRecipient" is a dummy variable that takes the value 1 if the dictator is Muslim and the recipient is a woman, and 0 otherwise. "SX $\rightarrow$ MaleRecipient" is a dummy variable that takes the value 1 if the dictator is Christian and the recipient is a man, and 0 otherwise. "SX $\rightarrow$ FemaleRecipient" is a dummy that takes the value 1 if the dictator is Christian and the recipient is a woman, and 0 otherwise. "Age" is equal to the age of the dictator. "Previous sessions" is a dummy variable that takes the value 1 if the dictator personally knows someone who participated in previous game sessions, and 0 otherwise. Standard errors are clustered at the individual dictator level. * and ** indicate statistical significance at the 5 and $1 \%$ levels, respectively. 
Table 4: Female SM and SX donations to female recipients, difference-of-means analysis

(A) Donations of female SM and SX dictators to all recipients

\begin{tabular}{c|c|c|c}
\hline & $\begin{array}{c}\text { Muslim Dictator } \\
(\mathrm{a})\end{array}$ & $\begin{array}{c}\text { Christian Dictator } \\
(\mathrm{b})\end{array}$ & $\begin{array}{c}\text { Difference } \\
(\mathrm{b}-\mathrm{a})\end{array}$ \\
\hline All female recipients & 1.38 & 2.06 & $\Delta_{1}=+0.68$ \\
(c) & $(\mathrm{N}=24)$ & $(\mathrm{N}=18)$ & $\mathrm{p}=0.04$ \\
\hline All male recipients & 0.96 & 1.67 & $\Delta_{2}=+0.71$ \\
$(\mathrm{~d})$ & $(\mathrm{N}=24)$ & $(\mathrm{N}=18)$ & $\mathrm{p}=0.01$ \\
\hline Difference & $\Delta_{3}=-0.42$ & $\Delta_{4}=-0.39$ & Diff-in-Diff: \\
$(\mathrm{d}-\mathrm{c})$ & $\mathrm{p}=0.16$ & $\mathrm{p}=0.18$ & Not sig. \\
\hline
\end{tabular}

(B) Donations of female SM and SX dictators to rooted French recipients

\begin{tabular}{c|c|c|c}
\hline & $\begin{array}{c}\text { Muslim Dictator } \\
\text { (a) }\end{array}$ & $\begin{array}{c}\text { Christian Dictator } \\
(\mathrm{b})\end{array}$ & $\begin{array}{c}\text { Difference } \\
(\mathrm{b}-\mathrm{a})\end{array}$ \\
\hline French female recipients & 1.38 & 2.11 & $\Delta_{1}=+0.73$ \\
(c) & $(\mathrm{N}=13)$ & $(\mathrm{N}=9)$ & $\mathrm{p}=0.14$ \\
\hline French male recipients & 0.73 & 1.67 & $\Delta_{2}=+0.94$ \\
$(\mathrm{~d})$ & $(\mathrm{N}=11)$ & $(\mathrm{N}=9)$ & $\mathrm{p}=0.01$ \\
\hline Difference & $\Delta_{3}=-0.65$ & $\Delta_{4}=-0.44$ & Diff-in-Diff: \\
$(\mathrm{d}-\mathrm{c})$ & $\mathrm{p}=0.08$ & $\mathrm{p}=0.35$ & Not sig. \\
\hline
\end{tabular}

(C) Donations of female SM and SX dictators to coethnic recipients

\begin{tabular}{c|c|c|c}
\hline & $\begin{array}{c}\text { Muslim Dictator } \\
(\mathrm{a})\end{array}$ & $\begin{array}{c}\text { Christian Dictator } \\
(\mathrm{b})\end{array}$ & $\begin{array}{c}\text { Difference } \\
(\mathrm{b}-\mathrm{a})\end{array}$ \\
\hline Coethnic female recipients & 0.33 & 2.33 & $\Delta_{1}=+2.00$ \\
$(\mathrm{c})$ & $(\mathrm{N}=3)$ & $(\mathrm{N}=3)$ & $\mathrm{p}=0.01$ \\
\hline Coethnic male recipients & 1.40 & 1.67 & $\Delta_{2}=+0.27$ \\
$(\mathrm{~d})$ & $(\mathrm{N}=5)$ & $(\mathrm{N}=3)$ & $\mathrm{p}=0.63$ \\
\hline Difference & $\Delta_{3}=+1.07$ & $\Delta_{4}=-0.66$ & Diff-in-Diff: \\
$(\mathrm{d}-\mathrm{c})$ & $\mathrm{p}=0.09$ & $\mathrm{p}=0.23$ & Sig. at 99\% \\
\hline
\end{tabular}


Table 5: Regression analysis of female SM and SX dictator donations

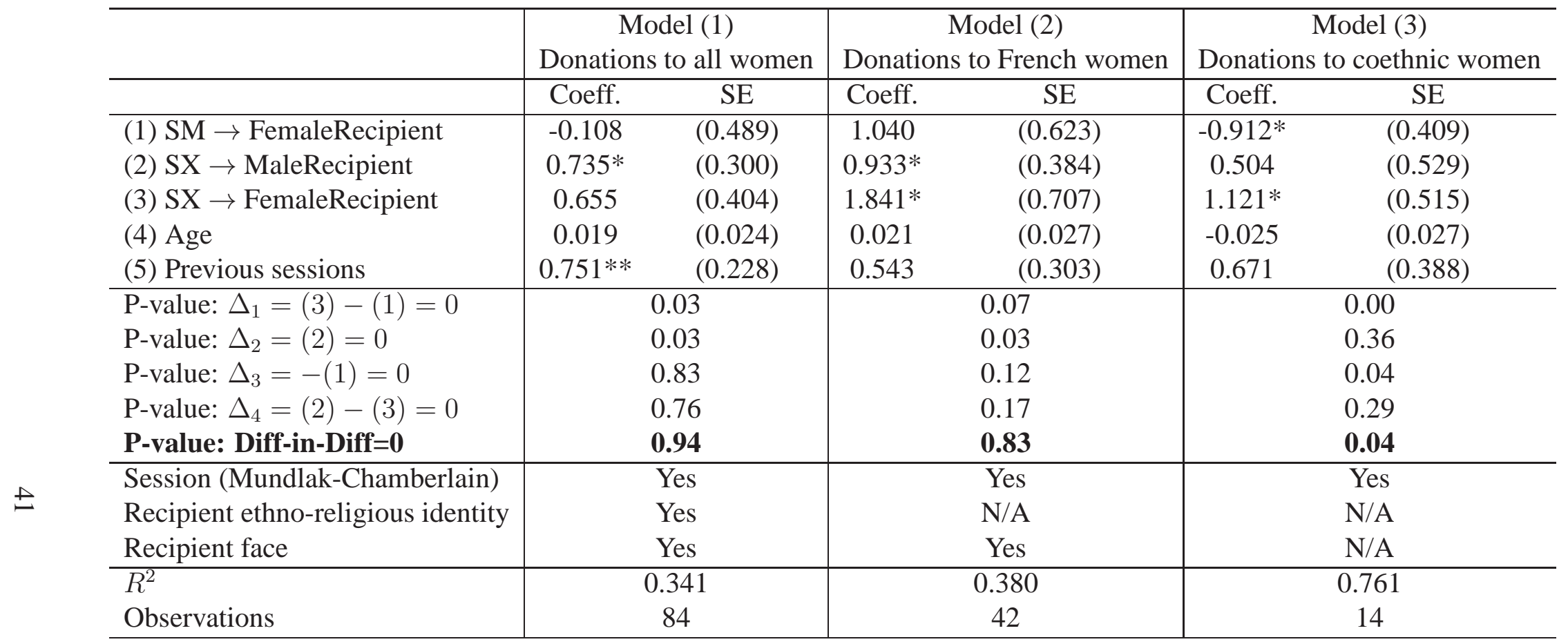

Notes: The table reports OLS estimates. The unit of observation is a dyad comprising of a SM or SX female dictator and one of the six recipients. The dependent variable is categorical, ranging from 0 (the dictator gives nothing to the recipient) to 5 (the dictator gives her total endowment to the recipient). In Model (1), the dependent variable is the donation to all recipients. In Model (2), it is the donation to French recipients. In Model (3), it is the donation to coethnic recipients. "SM $\rightarrow$ FemaleRecipient" is a dummy variable that takes the value 1 if the dictator is Muslim and the recipient is a woman, and 0 otherwise. "SX $\rightarrow$ MaleRecipient" is a dummy variable that takes the value 1 if the dictator is Christian and the recipient is a man, and 0 otherwise. "SX $\rightarrow$ FemaleRecipient" is a dummy that takes the value 1 if the dictator is Christian and the recipient is a woman, and 0 otherwise. "Age" is equal to the age of the dictator. "Previous sessions" is a dummy variable that takes the value 1 if the dictator personally knows someone who participated in previous game sessions, and 0 otherwise. Standard errors are clustered at the individual dictator level. * and ** indicate statistical significance at the 5 and $1 \%$ levels, respectively. 
Table 6: Testing the link between gender norms and labor market outcomes (channels 1 and 2)

\begin{tabular}{|c|c|c|c|c|c|c|c|}
\hline & Human capital & \multicolumn{5}{|c|}{ Bargaining power } & \\
\hline & $\begin{array}{l}\text { Educ. attain. } \\
\text { (1) }\end{array}$ & $\begin{array}{l}\text { Labor force } \\
\text { (2) }\end{array}$ & $\begin{array}{l}\text { Fem. 1st mig. } \\
\text { (3) }\end{array}$ & $\begin{array}{c}\text { Co-wives } \\
\text { (4) }\end{array}$ & $\begin{array}{c}\text { Polygamous } \\
\text { (5) }\end{array}$ & $\begin{array}{c}\text { Fem. head hh } \\
\text { (6) }\end{array}$ & $\begin{array}{l}\text { Nbr. children } \\
\text { (7) }\end{array}$ \\
\hline (1) Muslim hh & & & $\begin{array}{l}-\mathbf{- 0 . 0 8 0} \\
(0.048)\end{array}$ & $\begin{array}{c}0.010 \\
(0.135)\end{array}$ & $\begin{array}{c}0.065 \\
(0.040)\end{array}$ & $\begin{array}{l}-\mathbf{- 0 . 0 9 9} \\
(0.059)\end{array}$ & $\begin{array}{l}0.218 * \\
(0.110)\end{array}$ \\
\hline (2) Female & & & $\begin{array}{c}0.031 \\
(0.042)\end{array}$ & $\begin{array}{l}0.015 \\
(0.147)\end{array}$ & $\begin{array}{l}-0.058 \\
(0.043)\end{array}$ & $\begin{array}{c}0.459 * * \\
(0.051)\end{array}$ & $\begin{array}{l}0.191^{*} \\
(0.095)\end{array}$ \\
\hline (3) Female SM & $\begin{array}{c}0.004 \\
(0.218)\end{array}$ & $\begin{array}{c}0.015 \\
(0.052)\end{array}$ & & & & & \\
\hline Respondent \& first migrant controls & Yes & Yes & Yes & Yes & Yes & Yes & Yes \\
\hline P-value: Diff-in-Diff=0 & 0.371 & 0.252 & & & & & \\
\hline$R^{2}$ & 0.117 & 0.439 & 0.029 & 0.202 & 0.030 & 0.289 & 0.390 \\
\hline
\end{tabular}

Notes: The table reports OLS estimates. The unit of observation is the individual for models (1) and (2), and the household for models (3) through (7). The dependent variables are: in model (1), categorical, ranging from 1 (no diploma) to 8 (more than two years post-secondary education); in model (2), a dummy variable that takes the value 1 if the respondent is a home-maker, has never worked, or is a student, and 0 otherwise; in model (3), a dummy variable that takes the value 1 if the respondent's maternal grandmother, paternal grandmother, or mother was the first to migrate to France, and 0 otherwise; in model (4), a dummy variable that takes the value 1 if the respondent's first female migrant to France had co-wives, and 0 otherwise; in model (5), a dummy variable that takes the value 1 if the respondent's first male migrant to France had more than one wife, and 0 otherwise; in model (6), a dummy variable that takes the value 1 if the head of the respondent's household is female, and 0 otherwise; in model (7), the respondent's number of children. "Muslim hh" is a dummy variable that takes the value 1 if the household is SM, and 0 if the household is SX. "Female" is a dummy variable that takes the value 1 if the respondent is female, and 0 if the respondent is male. "Female SM" is a dummy variable that takes the value 1 if the respondent is a female SM, and 0 otherwise. "Male SX" is a dummy variable that takes the value 1 if the respondent is a male SX, and 0 otherwise. "Female SX" is a dummy variable that takes the value 1 if the respondent is a female SX, and 0 otherwise. The omitted category is the male SM. "Respondent \& first migrant controls" includes the education level of the respondent's first migrant to France, the number of years since arrival in France, and the age of the respondent. Standard errors are robust. * and $* *$ indicate statistical significance at the 5 and $1 \%$ levels, respectively. 
Table 7: Testing the link between gender norms and labor market outcomes (channel 3)

\begin{tabular}{l|c|c}
\hline & \multicolumn{2}{|c}{ French beliefs about... } \\
\hline (1) SM $\rightarrow$ French female recipient & male behavior: model (1) & female behavior: model (2) \\
& $0.332^{* *}$ & 0.232 \\
$(2) \mathrm{SX} \rightarrow$ French male recipient & $(0.122)$ & $(0.119)$ \\
& 0.041 & -0.073 \\
& $(0.086)$ & $(0.103)$ \\
(3) SX $\rightarrow$ French female recipient & $0.430^{* *}$ & 0.153 \\
& $(0.116)$ & $(0.128)$ \\
\hline Guesser controls & Yes & Yes \\
Recipient fixed effects & Yes & Yes \\
Dictator fixed effects & Yes & Yes \\
Computer fixed effects & Yes & Yes \\
Session fixed effects & Yes & $\mathbf{0 . 9 4 6}$ \\
\hline P-value: Diff-in-Diff=0 & $\mathbf{0 . 6 8 0}$ & 0.349 \\
\hline$R^{2}$ & 0.442 & 420 \\
Observations & 432 & . \\
\hline
\end{tabular}

Notes: The table reports OLS estimates. The unit of observation is a triad comprising of a rooted French guesser, a SM or SX dictator and a rooted French recipient. The dependent variable is categorical, ranging from 0 (the respondent believes nothing was given to the recipient) to 5 (the respondent believes the total endowment was given to the recipient). "SM $\rightarrow$ French female recipient" is a dummy variable that takes the value 1 if the respondent is guessing about $\mathrm{SM}$ dictator donations to French female recipients, and 0 otherwise. "SX $\rightarrow$ French male recipient" is a dummy variable that takes the value 1 if the respondent is guessing about SX dictator donations to French male recipients, and 0 otherwise. "SX $\rightarrow$ French female recipient" is a dummy variable that takes the value 1 if the respondent is guessing about SX dictator donations to French female recipients, and 0 otherwise. The omitted category is the guess about SM donations to French male recipients. "Guesser controls" include the guesser's sex, age, education, income and religiosity. Model (1) evaluates the determinants of rooted French beliefs about male behavior. Model (2) evaluates the determinants of rooted French beliefs about female behavior. Standard errors are robust. * and ** indicate statistical significance at the 5 and $1 \%$ levels, respectively. 
Table 8: Summary of results for tests of channels linking religion to economic performance

\begin{tabular}{|l|l|}
\hline \hline \multicolumn{2}{c}{ Channel 1: Do female SM have lower human capital than female SX? } \\
\hline \hline Indicator & Result \\
\hline Education level & No significant difference \\
\hline \hline \multicolumn{2}{|c|}{ Channel 2: Do female SM have less bargaining power than female SX? } \\
\hline \hline Indicator & Result \\
\hline Labor force participation & No significant difference \\
Female first migrant & No significant difference \\
First female migrant had co-wives & No significant difference \\
First male migrant was polygamous & No significant difference \\
Head of household is a woman & SM households less likely (90\% confidence) \\
Number of children & SM households have more children $(95 \%$ confidence) \\
\hline \hline \multicolumn{2}{|c}{ Channel 3: Do French recruiters perceive SM gender norms? } \\
\hline \hline Indicator & Result \\
\hline French beliefs about SM/SX donations & No significant difference \\
\hline \hline
\end{tabular}


Table 9: Regression analysis of gender norms before migration

\begin{tabular}{l|c|c|c}
\hline & Spouse present: model (1) & Summoned others: model (2) & Influenced by others: model (3) \\
\hline (1) Female SM respondent & -0.014 & $-0.031^{*}$ & 0.034 \\
& $(0.013)$ & $(0.013)$ & $(0.016)$ \\
(2) Male SX respondent & 0.028 & -0.034 & 0.013 \\
& $(0.037)$ & $(0.023)$ & $-0.039)$ \\
(3) Female SX respondent & -0.048 & -0.027 & $(0.031)$ \\
& $(0.024)$ & $(0.032)$ & Yes \\
\hline Respondent controls & Yes & Yes & Yes \\
Interviewer controls & Yes & Yes & $\mathbf{0 . 0 1}$ \\
Year fixed effects & Yes & $\mathbf{0 . 2 0}$ & 0.040 \\
\hline P-value: Diff-in-Diff=0 & $\mathbf{0 . 2 6}$ & 0.045 & 494 \\
\hline$R^{2}$ & 0.047 & 497 & 49 \\
\hline
\end{tabular}

Notes: The table reports OLS estimates. The unit of observation is the individual SM or SX respondent in the Afrobarometer survey. The dependent variable in model (1) is based on Afrobarometer questions Q99 (round 2002) and Q104 (rounds 2005 and 2008). It is a dummy variable coded as 1 if the interviewer noted that the respondent's spouse was immediately present during the interview, and 0 otherwise. The dependent variable in model (2) is based on Afrobarometer questions Q100 (round 2002) and Q105A (rounds 2005 and 2008). It is a dummy variable coded as 1 if the interviewer noted that the respondent checked with others before answering any question, and 0 otherwise. The dependent variable in model (3) is based on Afrobarometer questions Q101 (round 2002) and Q105B (rounds 2005 and 2008). It is a dummy variable coded as 1 if the interviewer noted that someone influenced the respondent's answers during the interview, and 0 otherwise. "Female SM respondent" is a dummy variable that takes the value 1 if the respondent is a female SM, and 0 otherwise. "Male SX respondent" is a dummy variable that takes the value 1 if the respondent is a male SX, and 0 otherwise. "Female SX respondent" is a dummy variable that takes the value 1 if the respondent is a female SX, and 0 otherwise. The omitted category is the male SM respondent. "Respondent controls" includes the age and education of the respondent; how often the respondent has gone without food in the previous year; and whether the household is in an urban or rural area. "Interviewer controls" includes the sex, age, education and urban/rural origins of the interviewer. Standard errors are robust and clustered at the regional level. * and $* *$ indicate statistical significance at the 5 and $1 \%$ levels, respectively. 
Figure 1: Variation in the ethno-religious identity of the recipients

\begin{tabular}{|c|c|c|c|c|c|c|c|}
\hline \multirow{2}{*}{ Firstname } & Version 1 & Sylvie & Georges & Khadija & Jean-Marc & Farida & Michel \\
\hline \multirow{2}{*}{ Type } & Version 2 & Sylvie & Mohammed & Joséphine & Jean-Marc & Christine & Aboubacar \\
\cline { 2 - 10 } & Version 1 & Rooted French & Rooted French & SM & Rooted French & North African & SX \\
\cline { 2 - 9 } & Version 2 & Rooted French & North African & SX & Rooted French & Rooted French & SM \\
\hline
\end{tabular}


Figure 2: Sample screenshot for the March 2010 experiment

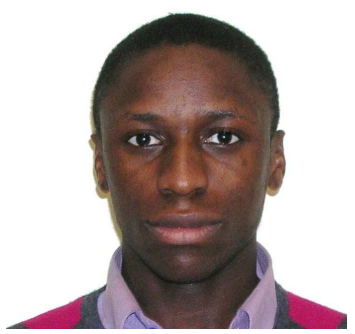

\section{Pierre}

Selon vous, combien Pierre a-t-il donné à ces différentes personnes?

Sylvie Eeorges Khadija Jean-Marc Farida Michel


Figure 3: Distribution of female Senegalese Muslim and Christian dictator donations to all female recipients

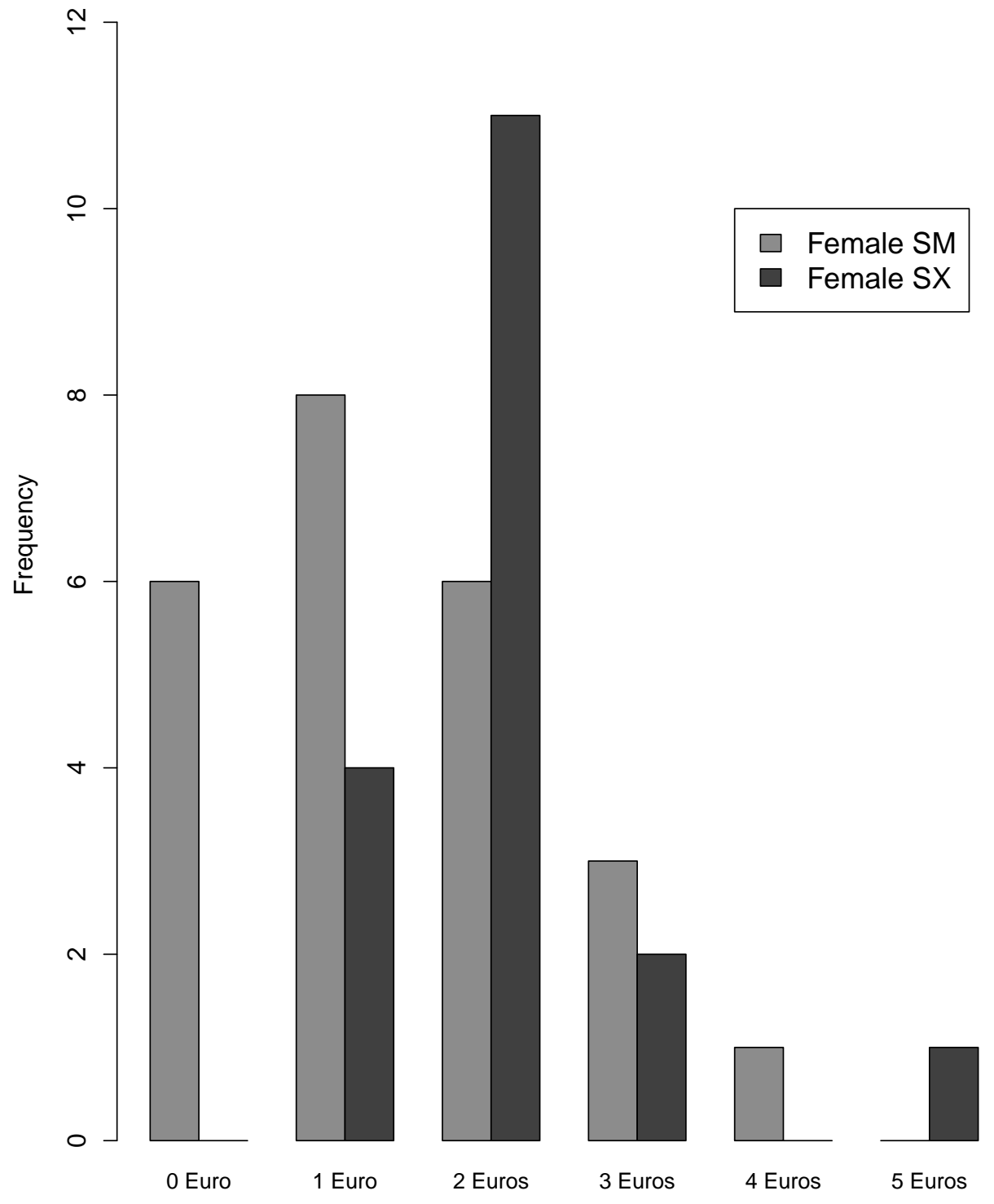


Figure 4: Distribution of male Senegalese Muslim and Christian dictator donations to all female recipients

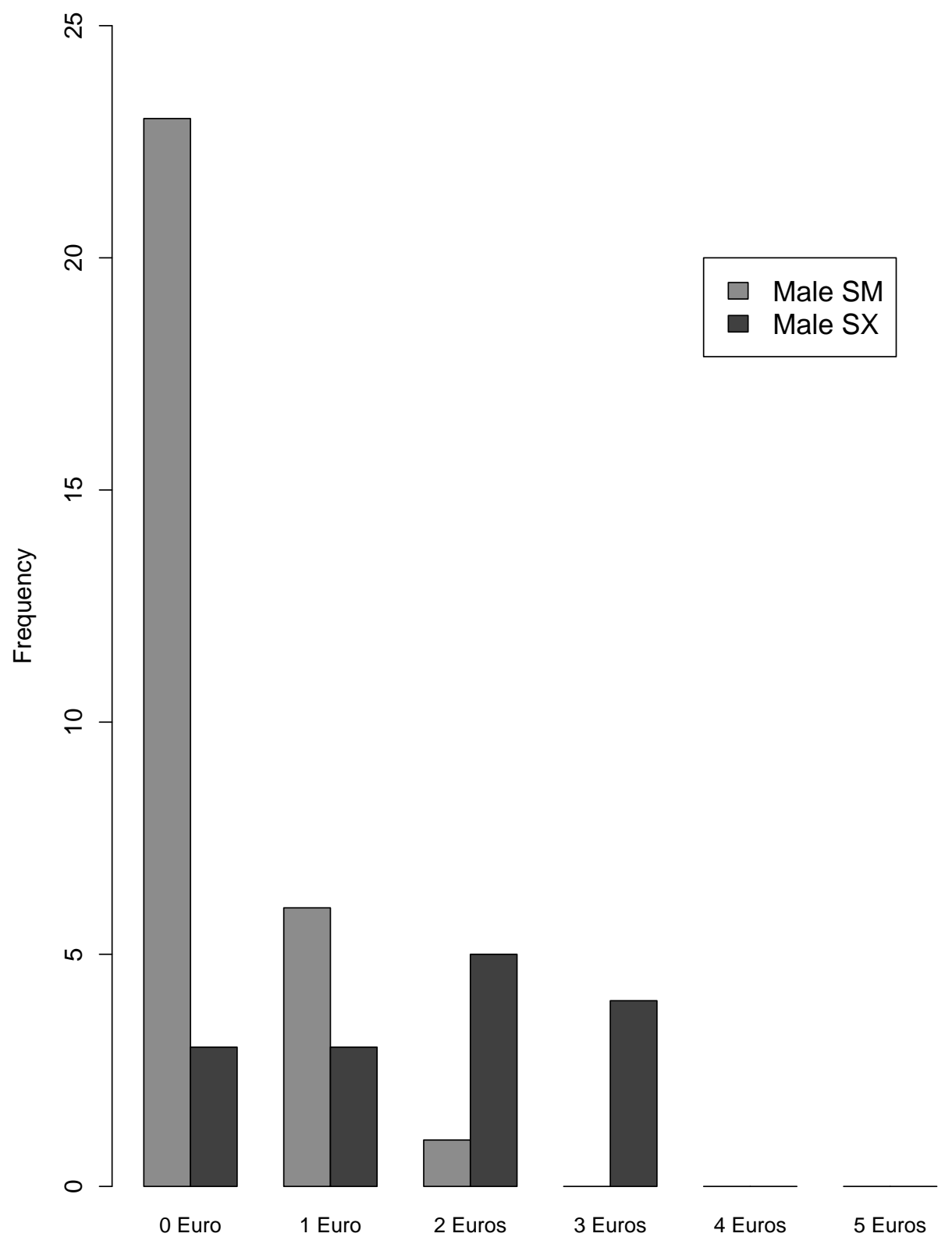

